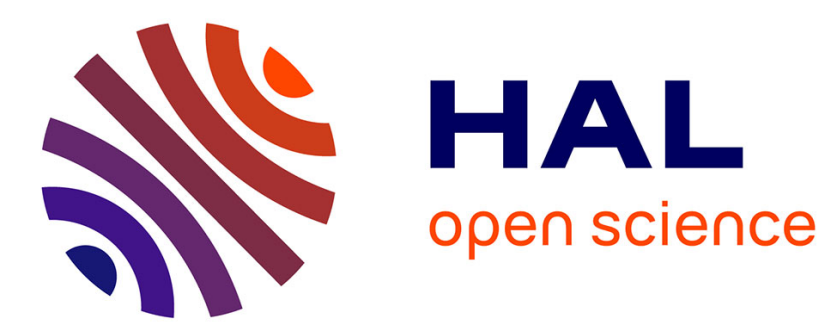

\title{
Suppliers as financial intermediaries: Trade credit for undervalued firms
}

Patrice Fontaine, Sujiao Zhao

\section{To cite this version:}

Patrice Fontaine, Sujiao Zhao. Suppliers as financial intermediaries: Trade credit for undervalued firms. Journal of Banking and Finance, 2021, 124, pp.106043. 10.1016/j.jbankfin.2021.106043 . hal03507994

\section{HAL Id: hal-03507994 \\ https://hal.science/hal-03507994}

Submitted on 3 Jan 2022

HAL is a multi-disciplinary open access archive for the deposit and dissemination of scientific research documents, whether they are published or not. The documents may come from teaching and research institutions in France or abroad, or from public or private research centers.
L'archive ouverte pluridisciplinaire HAL, est destinée au dépôt et à la diffusion de documents scientifiques de niveau recherche, publiés ou non, émanant des établissements d'enseignement et de recherche français ou étrangers, des laboratoires publics ou privés. 


\title{
Suppliers as Financial Intermediaries: Trade Credit for
}

\author{
Undervalued Firms ${ }^{1}$ \\ Patrice C. Fontaine ${ }^{a, b}$ and Sujiao Zhao $c, d$ \\ ${ }^{a}$ CNRS (EUROFIDAI) \\ ${ }^{\text {b }}$ Léonard de Vinci Pôle Universitaire, Research Center \\ ${ }^{\mathbf{c}}$ Banco de Portugal \\ ${ }^{\mathrm{d}}$ University of Porto (cefUP)
}

\section{Revised Version}

\begin{abstract}
Given the high levels of trade credit on firms' balance sheets, understanding the factors that drive its supply and demand are of great importance. We examine the impact of undervaluation, in which information asymmetry is typically high, on a firm's use of trade credit. We find that the firm's suppliers play an important role in providing temporary bridge financing when a firm is undervalued and that trade credit is substituted for short-term financial debt subsequent to stock undervaluation. The positive effect of undervaluation on trade credit is robust to various undervaluation measures and alternative empirical specifications. These effects vary with a firm's dependence on external finance and with the information environment in which the undervalued firm operates. In addition, small customers who have long-term relationships with their suppliers are more likely to obtain trade credit when facing stock market undervaluation.
\end{abstract}

Keywords: Undervaluation; Trade credit; Information advantage; Implicit equity stake JEL Classification: G3, G30, G32, D2, D21

${ }^{1}$ We thank Nihat Aktas, Janis Berzins, Eric De Bodt, François Derrien, Georges Dionne, Pascal François, Christophe Godlewski, Franck Moraux, Patrick Navatte, Pascale Valery, Rong Wang, Wenfeng Wu, Jinqiang Yang, and Nancy Marie Brown, as well as seminar participants at HEC Montréal, IGR Rennes, Bank of Portugal, University of Porto, University of Minho, the AFFI 2015 annual conference, the FMA 2015 Orlando meeting, the FMA 2017 Lisbon meeting, for their valuable comments and suggestions. Funding for this project was provided by a grant from La Région Rhône-Alpes.

Corresponding author: Patrice C. Fontaine, EUROFIDAI, 150 rue de la chimie, Domaine Universitaire, CS 40700 - 38058 Grenoble Cedex 9 France; Tel: +33 4766353 60; Fax: +33 476 6353 86; Email: patrice.fontaine@eurofidai.org. 


\title{
Suppliers as Financial Intermediaries: Trade Credit for
}

\section{Undervalued Firms}

\begin{abstract}
Given the high levels of trade credit on firms' balance sheets, understanding the factors that drive its supply and demand are of great importance. We examine the impact of undervaluation, in which information asymmetry is typically high, on a firm's use of trade credit. We find that the firm's suppliers play an important role in providing temporary bridge financing when a firm is undervalued and that trade credit is substituted for short-term financial debt subsequent to stock undervaluation. The positive effect of undervaluation on trade credit is robust to various undervaluation measures and alternative empirical specifications. These effects vary with a firm's dependence on external finance and with the information environment in which the undervalued firm operates. In addition, small customers who have long-term relationships with their suppliers are more likely to obtain trade credit when facing stock market undervaluation.
\end{abstract}

Keywords: Undervaluation; Trade credit; Information advantage; Implicit equity stake JEL Classification: G3, G30, G32, D2, D21 


\section{Introduction}

Despite the high implicit interest costs of trade credit, firm balance sheets show high levels of this form of financing. For U.S. firms, for example, trade credit is more significant than short-term financial debt, representing roughly one-third of total financial liabilities, as illustrated in Figure I. Given the non-trivial role of trade credit in firms' financing decisions, understanding the potential factors that drive the supply and demand of such credit has been the focus of academic research for many years, beginning with Smith (1987). A recent strand of the literature (e.g., Giannetti et al., 2011; Daripa and Nilsen, 2011; Garcia-Appendini and Montoriol-Garriga, 2013; Casey and O'Toole, 2014; and Shenoy and Williams, 2017) focuses on the role of trade credit at times when firms face financial constraints and banks are exposed to high liquidity risk. We add to this literature by investigating whether a firm's choice of trade credit is affected by firm undervaluation. $^{1}$

\section{[Insert Figure I about here]}

Trade credit refers to contractual obligations provided by non-financial institutions. These obligations include, but are not limited to, a firm's delayed payments to its suppliers and other forms of credit from economically linked companies. Our paper focuses on the former, that is, on money owed to suppliers.

In the classical approach to understanding a firm's use of trade credit, Smith (1987) considers that the firm's suppliers and other third parties hold less information about the firm's prospects than do the financial markets, therefore the interest rate a bank charges will usually be lower than

\footnotetext{
${ }^{1}$ Myers and Majluf(1984) suggest that undervaluation, also referred to as the "lemon" problem, can arise due to information frictions.
} 
the implicit interest rate charged by the firm's suppliers. However, directly comparing the implicit cost of trade credit to the cost of bank credit is difficult, if not impossible. From the buyer's perspective, the use of trade credit may imply only that the buyer accepts paying a higher price to guarantee the quality of the goods or services provided by the seller, or to make a commitment, not to divert the credit for an unprofitable purpose (Burkart and Ellingsen, 2004). The use or extension of trade credit could be a positive signal by the seller in this case, as it sends a message to outsiders that the buyer's situation is better than the outsiders may suspect.

In this paper, we analyze the situation in which managers consider their firm to be undervalued because the banks and financial markets do not possess enough information about the firm's prospects. In line with Biais and Gollier (1997) and in opposition to Smith (1987), we expect that economically linked companies such as suppliers hold better information about a firm than do financial investors, at times when the stock market undervalues the firm. Suppliers can be considered as holding an implicit equity stake in their clients; therefore, they have a natural tendancy to accept an extension of trade credit when their clients are temporarily undervalued by the market. This, in turn, sends a message to outsiders that the buyer's situation is better than the outsiders suspected (Aktas et al., 2012). For instance, the stock market may have only limited information about the future prospects of a young firm. In this situation, even a bank that has established a lending relationship with the firm may not be willing to extend as much flexibility as the firm desires, for fear that the firm might divert money into unprofitable projects at the bank's expense. Trade credit is desirable, subsequent to the firm's undervaluation, because credit in the form of goods or services is harder to divert than money.

Moreover, a supplier who specializes in a unique product that has no close substitutes, and/or that has a limited number of customers, may be inclined to help out its "shocked" customer due to 
a natural interest in that customer's long-term health. Indeed, Smith (1987) notes that in the presence of a non-trivial financial stake, the seller has incentives to "distinguish between buyers who require temporary assistance ... and those likely to default and who are not expected to generate sufficient future quasi-rents to justify continued extension of credit." In the survey of $\mathrm{Ng}$ et al. (1999), a significant number of the firms studied admit that they are willing to extend their trade credit period, especially for long-term customers.

In this paper, we consider three hypotheses. First, we hypothesize that firms increase their use of trade credit when they are temporarily undervalued by the market. Second, we expect undervalued firms to substitute trade credit for short-term financial debt. Third, we hypothesize that the link between trade credit and undervaluation depends on the relationship between the firm and its suppliers. We provide theoretical underpinnings of these three hypotheses in Section 2.

To formally test whether firms increase their use of trade credit when they are temporarily undervalued by the financial markets, we start by applying a specification in the spirit of Rajan and Petersen (1997), where a firm's use of trade credit is modeled as a function of undervaluation, firm characteristics, and firm and year fixed effects. Then, to gauge the effect in relative terms and to analyze whether undervalued firms substitute trade credit for short-term financial debt, we employ a constrained regression approach, as in Fama and French (2012). In this approach, a firm's financing decisions are simultaneously determined in a unified framework where cash flow constraints are imposed. The purpose of this specification is to tease out the credit provided by the suppliers from the credit provided by other conventional lenders (i.e., the total of stock market investors and financial institutions).

Identifying the undervaluation effect is empirically challenging. In particular, the stock of firms with weak fundamentals is more likely to be valued low, while at the same time common 
misvaluation measures, such as the market-to-book ratio or stock returns, are likely to be correlated with the firm's characteristics, as well as with its choice of financing, such as the use of trade credit. Consequently, any observed effects may simply be driven by the omitted variables in the error term. Therefore, we need a "shock" to the firm's stock valuation that is exogenous to the firm's fundamentals.

To correct this potential endogeneity bias in a firm's stock undervaluation, we follow a recent strand of literature that instruments firm undervaluation by the price pressure induced by large outflows of mutual funds (see, e.g., Coval and Stafford, 2007; Khan et al., 2012; Edmans et al., 2012; and Eckbo et al., 2018). For this instrumental variables (IV) estimation to be valid, it must meet the relevance condition (i.e., the mutual fund outflow should be associated with stock undervaluation) and the exclusion restriction (i.e., the mutual fund outflow only affects trade credit through its effect on stock undervaluation). Mutual funds that experience large capital outflows are subject to a selling pressure and find it difficult to rebalance their portfolios rationally. This illiquidity issue imposes a negative price pressure on firms whose stock is held by these "pressured" mutual fund managers; this price pressure further drives the firm's stock price to depart from its fundamental value. This relationship implies that large mutual fund outflows should be positively related to the firm's stock undervaluation, thus meeting the IV relevance condition. In addition, the price pressure induced by the aggregate mutual fund flow represents an exogeneous variation in the firm's stock price, as fund transactions and the fundamentals of individual stocks should be orthogonal; the price pressure, therefore, should also be orthogonal to the firm's financing decisions, satisfying the IV exclusion restriction.

Our results indicate that suppliers play an important part in alleviating firm undervaluation, thanks to the fact that trade credit serves as bridge financing when a firm is temporarily 
undervalued. Specifically, we find a positive association between firm undervaluation and trade credit, and that firms substitute trade credit for short-term financial debt. The effect of undervaluation on a firm's choice to use trade credit is more prominent among firms with a high dependence on external finance and with more information asymmetry issues. Finally, using a manually collected matched supplier-customer sample, we show that the effect of a firm's undervaluation on its use of trade credit varies depending on the firm's relationship with its suppliers. Our findings hold up to a battery of robustness tests, such as employing alternative misvaluation measures, using alternative estimation models, and specifying ex ante publicly available information at the time of issuance.

Our research brings new evidence to the trade credit literature. Previous studies of trade credit (e.g., Choi and Kim, 2005; Cuñat, 2007; Garcia-Appendini and Montoriol-Garriga, 2013; and Casey and O'Toole, 2014) emphasize the role of trade credit in providing additional liquidity to firms that are suffering from temporary liquidity shocks or monetary tightening. Our paper complements this literature by providing an alternative explanation for the dynamics of trade credit usage. Specifically, we explain the increased use of trade credit from the perspective of stock market undervaluation.

Our work is closely related to a recent strand of research looking into the financial and real effects of firm misvaluation by capital markets. Harford et al. (2015) investigate how firms make borrowing and investment decisions in misvalued credit markets; using the ex post accuracy of credit ratings, they find that firms make use of ratings inaccuracies to employ more debt and to increase investment. Estimating the parameters of a dynamic investment mode, Warusawitharana and Whited (2016) show that firm misvaluation induces large changes in the financial and investment policies of firms. Hau and Lai (2013) identify substantial underpricing, using firesales 
of distressed funds, and find significant underinvestment and underemployment in underpriced firms. Edmans et al. (2012) use mutual fund redemptions as an instrumental variable for stock valuation and find a strong relation between market prices and takeover activities. Ben-David et al. (2015) use short interest rates to measure misvaluation and find a strong link between short interest rates and merger activities. Eckbo et al. (2018), while testing bidder opportunism in the decision to use stocks as deal payments in takeovers, also use large aggregate mutual fund outflows to identify exogeneous variations in bidders' pricing. By examining firms' access to alternative sources of credit, our research complements and extends these studies. Our results point to firms' attempts to alleviate capital market imperfections, specifically firm undervaluation, by turning to transitional funds, i.e., trade credit, while waiting for their stock prices to recover.

The remainder of this paper is organized as follows. Section 2 develops our hypotheses. Section 3 describes our data and variables. Section 4 reports our empirical results on firms' use of trade credit in the presence of undervaluation. Section 5 considers the role of the supplier relationship. Section 6 presents our robustness checks. Section 7 concludes.

\section{Hypotheses}

Firm undervaluation has several theoretical explanations, all pointing to situations in which the stakeholders disagree on the value of a firm. Financial investors, including stock market investors and financial institutions (banks, for example), believe that the price of a stock reflects the true value of a firm, whereas the firm's managers estimate a higher value. Managers (as insiders) can be presumed to have superior information about the firm's prospects, as compared to the financial investors (outsiders), who thus undervalue the firm. Under these circumstances, the market timing 
theory concludes that the managers will not issue equity to finance the firm's activities, because they anticipate that the investors will correct their expectations.

Baker and Wurgler (2002) present two versions of equity market timing. The first is the dynamic form of Myers and Majluf (1984), which models rational investors and managers with an adverse selection cost that varies across firms over time. The second version considers irrational investors (or managers) and models time-varying mispricing, or the time-varying perception of mispricing (e.g., La Porta et al., 1997; Frankel and Lee 1998; and Shleifer, 2000). We do not distinguish, in this paper, between one version of equity market timing and the other. Indeed, we assume, as in the traditional equity timing models, that financial investors and managers do not have the same information about the firm. Therefore, the undervaluation of the firm is a function of the information difference between financial investors (outsiders) and managers (insiders), regardless of whether or not the use of that information is rational.

It is worthwhile to note that the conventional equity timing approaches only consider two stakeholders, i.e., stockholders and debtholders, and the choice between equity and financial debt. Subsequent researchers (e.g., Flannery, 1986; Diamond, 1991; and Diamond and He, 2014), however, show that in the presence of asymmetric information, firms undervalued by the market prefer short-term debt to long-term debt. These analyses suggest that firms prioritize their sources of financing in this order: first, short-term debt; second, long-term debt; and third, stock issues. We consider a fourth financing option, trade credit, or a firm's delayed payments to its suppliers, and a third type of stakeholder, i.e., economically linked companies, which are either sellers of goods or providers of services to the firm in question.

Our first hypothesis is that when a firm is undervalued, the firm will make more use of trade credit. Compared to banks and financial markets, economically linked companies can hold 
superior information about the firm (e.g., Biais and Gollier, 1997). The sellers of goods (or providers of services) to this firm have a better knowledge of the product market in which the firm operates. Therefore, the managers of the selling firms can derive more accurate expectations and inferences about the prospects of their buyer's market. Moreover, the sellers' managers are often in direct contact with the buyer and thus have a better view of its true value. This continuous interaction generates valuable "soft information," which mitigates any information asymmetries between a firm and its stakeholders when the firm is temporarily undervalued due to information frictions. Additionally, the monitoring of credit quality can occur as a by-product of selling, when a manufacturer's sales representatives visit the borrower regularly (Mian and Smith, 1992). There is also evidence that external investors interpret the extension of trade credit as a positive signal (Aktas et al., 2012). Above all, the implicit cost of using trade credit can ultimately be lower than the cost of a financial loan, especially if we deduct the cost of the guarantees.

Our second hypothesis is that when a firm is undervalued, the firm will not only use more trade credit (as in our first hypothesis), it will also use less short-term financial debt. It is well established that firms choose various sources of financing to manage different growth aspects. Short-term financial debt and trade credit are often chosen to meet a firm's liquidity needs (e.g., GarciaAppendini and Montoriol-Garriga, 2013), while long-term financial debt and stocks are often used to manage long-term growth. According to Myers and Majluf (1984), firms substitute financial debt for stock issues in the presence of information asymmetry. Yet, when firms are searching for solutions to fill a liquidity shortage due to temporary undervaluation, trade credit tends to act as a substitute for short-term financial debt.

Our third hypothesis is that when a firm is undervalued, the increase in its use of trade credit depends on the relationship between the firm and its suppliers. Sellers have an economic interest 
or a financial stake in maintaining a good business relationship with their buyers. For instance, a supplier who specializes in a unique product that has no close substitutes, and/or which has a limited number of customers, may be obliged to help out its "shocked" customer due to a natural interest in that customer's long-term health. The strength of the links between suppliers and customers may convince suppliers to help firms temporarily in a bad situation. Suppliers may even lend to a buyer at an interest rate lower than the interest rate the seller itself pays to the bank. The specific characteristics of trade credit, including proximity, bargaining over the sale price, economic interaction, guarantees, etc., explain why the implicit costs of such loans for a buyer may be lower "in fine" than those of financial short-term credit. From this viewpoint, the stronger the relationship between suppliers and customers, the more trade credit the suppliers will extend.

\section{Data and Variables}

\subsection{Data}

Our sample is drawn from the CRSP/Compustat Merged database of all U.S. firms over the period from 1991 through 2016. Following the previous literature, we exclude financial firms from our sample (i.e., firms with SIC codes between 6000 and 9000), because the financing policies and business models of these firms are highly different from those of other firms. We obtain quarterly mutual fund flow data from CRSP and mutual fund holding data from Thomson Reuters, using Mutual Fund Links (MFLINKS) to match the same funds in the two databases. For a firm to be included in our sample, we require complete information on all our regression variables (as described in Appendix A). Observations with negative book equity, or with common equity value superior to total assets at the end of fiscal year $\mathrm{t}-1$, are eliminated. We further discard observations with common equity value superior to total assets at the beginning of the fiscal year. Moreover, 
we winsorize positive earnings (Pos Yt), dividends (Dt), and the lagged value-to-price ratio (UNt1) at $99.5 \%$ of the annual distribution, and winsorize change in assets (dAt), stocks issued (dSt), and negative earnings (NegYt) at $0.5 \%$ of the annual distribution. To address concerns that a mutual fund may be trading based on private information about a firm's fundamentals, we follow Edmans et al. (2012) and exclude specialized funds that focus on very specific industries. We follow an incremental approach to calculate changes in trade credit, i.e., the difference of a firm's accounts payable between year $\mathrm{t}$ and year $\mathrm{t}-1$, scaled by the firm's total assets at the beginning of

fiscal year $\mathrm{t}$ and multiplied by 100 (i.e., $d T C_{t}=100 \times\left(\right.$ Accounts Payable $_{t}-$ Accounts Payable $\left._{t-1}\right) /$ Total Assets t-1 $_{1}$. Since we compute each firm's intrinsic value based on a three-year forecast horizon (i.e., data for $t, t+1$, and $t+2$ are needed to perform this calculation) and use the one-period lagged value-to-price ratio in our regression models, the final sample for our main analyses covers the period 1991 to 2014, with 5,377 firms and 51,109 observations.

\subsection{Variables}

\subsubsection{Measuring Undervaluation}

There is a long-running debate about whether and to what extent firms are mispriced relative to their fundamental value. Proponents of the efficient market theory believe that a firm's stock price is the best measure of the market's expectations about the firm's performance and that there is no room for mispricing. A large body of survey and academic evidence, however, shows this belief may not always hold true. A significant number of executives believe that the market underestimates the value of their stock, according to a 1984 Louis Harris poll of top executives from more than 600 firms and a survey by Tsetsekos et al. (1991) on 1000 large firms. Managers with private information about the real status of a firm are able not only to identify valuation errors, but to design financial strategies to exploit those errors (e.g., Graham and Harvey, 2001; Bancel 
and Mittoo, 2004; Jensen, 2005; Baker et al., 2007; Polk and Sapienza, 2009; D’Mello and Shroff, 2000; Fama and French, 2012; and Dittmar and Field, 2015). ${ }^{2}$ Three recent studies, Hau and Lai (2013), Warusawitharana and Whited (2016), and Eckbo et al. (2018), show that capital market misvaluation significantly affects a firm's investment, takeover, and employment decisions.

Although the debate on the persistence of stock mispricing continues, there is no question that temporary stock mispricing exists. We construct a measure that captures the misvaluation component of a firm's stock in the following way.

Like previous researchers, we measure a firm's undervaluation based on the firm's value-toprice ratio, calculated as the firm's intrinsic value divided by the firm's stock price. Taking into account the firm's future cash flows, this measure allows us to filter out the firm's growth options, thus allowing us to further distinguish the misvaluation component from the fair valuation component. The firm's intrinsic value is estimated in the framework of the residual income model, assuming managers have perfect foresight. Previous studies find that misvaluation measured by the residual income model generally outperforms other traditional market multiples (such as priceto-book, earnings-to-book, or dividend-to-book ratios) in predicting stock returns, security issuance/repurchase decisions, and merger/takeover activities. In a robustness test, we relax the assumption of perfect foresight using analyst forecast data from $I / B / E / S$. The sample size shrinks by half, but the results are qualitatively similar.

The original version of the model calculates a firm's intrinsic value based on an infinite horizon framework, in which the intrinsic value is expressed as the book value of the firm at time t, plus

\footnotetext{
${ }^{2}$ Subsequent studies raise questions about the significance and persistence of equity market timing, given the existence of non-trivial transaction costs (e.g., Alti, 2006; and Flannery and Rangan, 2006).
} 
the discounted future expected earnings in excess of the expected return on book equity. To simplify the estimation, we follow previous studies and employ a three-year forecast horizon, which yields:

$$
\begin{gathered}
\widehat{V}_{t}=B_{t}+\frac{E_{t}\left[\left(R O E_{t+1}-r_{e}\right) \times B_{t}\right]}{\left(1+r_{e}\right)}+\frac{E_{t}\left[\left(R O E_{t+2}-r_{e}\right) \times B_{t+1}\right]}{\left(1+r_{e}\right)^{2}}+T V, \\
\mathrm{TV}=\frac{E_{t}\left[\left(R O E_{t+3}-r_{e}\right) \times B_{t+2}\right]}{\left(1+r_{e}\right)^{2} \times r_{e}},
\end{gathered}
$$

where $\widehat{V}_{t}$ denotes the estimated intrinsic value of the firm's stock at time $t ; B$ is the time $t$ book equity per share; $E_{t}($.$) is the expectation operator conditional on the information set at time t$; $R O E_{t+i}$ is the return on equity at time $t+i ; r_{e}$ is the cost of equity conditional on information available at time $t$; and $T V$ is the terminal value, estimated by treating the time $t+3$ abnormal earnings as a perpetuity.

Future book equity, $B_{t+i}$, is computed based on the accounting principle of "clean surplus" as:

$$
B_{t+i}=B_{t+i-1}+E P S_{t+i-1} \times(1-k)
$$

where EPS is the earnings per share from the previous period, and $k$ is the payout rate (dividends divided by the income before extraordinary items) at time $t$. If earnings are negative, $k$ is estimated as $6 \%$ of total assets $(k=$ dividends $/(0.06 \times$ Total Assets $))$. Computations with $k$ less than 0 or over 1 are removed. Any negative $B_{t}$ is eliminated. We further require the terminal value $(T V)$ to be non-negative. (It is worth noting, however, that our results are robust to including observations with negative terminal value, as shown in our robustness tests.) We acknowledge that our implementation of a three-year forecast horizon may underestimate firms with growth options to be exercised over the long run. However, as the relation between stock undervaluation and trade 
credit is more short-term (see Table IX), we believe that the value-to-price ratio computed under the three-year horizon is reasonable in our research context. Previous researchers, e.g., Lee et al. (1999), demonstrate that the choice of a forecast horizon beyond three years does not affect the quality of the estimates for a firm's intrinsic value. Moreover, we obtain qualitatively similar results from the estimates of intrinsic value using four- and five-year forecast horizons; these results are available on request.

Return on equity is calculated as:

$$
R O E_{t+i}=\frac{E P S_{t+i}}{\left(B_{t+i-1}+B_{t+i-2}\right) / 2}
$$

The annualized cost of equity, $r_{e}$, is predicted using the CAPM model based on monthly return data from CRSP. The market return is measured by the value-weight return of all CRSP firms incorporated in the U.S. and listed on the NYSE, AMEX, or NASDAQ exchanges; the risk-free rate is the one-month T-bill rate; and the market risk premium is estimated over the past thirty years. Most researchers find robust results irrespective of the asset pricing model used (D'Mello and Shroff, 2000), while some report that estimates using augmented models are noisier than those provided by the single factor CAPM model (Elliott et al., 2008). We find that adopting the alternative cost of capital model with various market premium measures leads to similar results; these results are available on request. ${ }^{3}$ We estimate the month- $t$ beta for each stock using a 60 -

3 These include: 1) different measures of intrinsic value using forecast horizons beyond three years, and 2) various estimates of the cost of capital, based on alternative asset pricing models (e.g., the Fama and French three-factor model and the Carhart four-factor model) and market premium measures (e.g., the market return measured by the S\&P 500 index minus the risk-free rate measured using the three-month T-bill rate, the 10-year and 20-year T-bond rates; or the market risk premium estimated over the past five years, from January 1945 to month $\mathrm{t}-1$, with a constant rate of $12.5 \%$, etc.). 
month rolling window, with at least 24 months of returns. As in Dong et al. (2012), the market risk premium is the annualized excess return of the CRSP value-weighted index over the annualized one-month Treasury bill rate over the past three decades. Lee et al. (1999) document that estimates of a firm's intrinsic value based on the short-term Treasury bill rates outperform those based on the long-term Treasury bond rates, because the former has a faster speed of mean reversion. To reduce the effect of outliers, we further restrict values of $r_{e}$ to within the range of $5 \%$ to $25 \%$.

In Section 6.2 (Table X), we conduct a battery of tests considering alternative misvaluation measures (e.g., the book-to-price ratio; Kropf, Robinson, and Viswanathan's (2005) firm-specific error; and the value-to-price ratio, for which ex ante publicly available information at the time of issuance, i.e., analysts' forecast data from $\mathrm{I} / \mathrm{B} / \mathrm{E} / \mathrm{S}$, is used to calculate the firm's intrinsic value). Our findings remain qualitatively similar.

\subsubsection{Mutual Fund Outflow}

To address the concern that conventional misvaluation measures and a firm's financing choices may be endogenous, we follow the previous literature by forming an instrumental variable for stock undervaluation based on the price pressure induced by large outflows of mutual funds that hold the firm's stocks (Coval and Stafford, 2007; Khan et al., 2012; Edmans et al., 2012; and Eckbo et al., 2018).

Mutual fund outflow is calculated for each stock-quarter based on large mutual fund capital flows, following Edmans et al. (2012), as illustrated below,

$$
\text { Outflow }_{j, t}=\frac{-F_{j, t}}{T A_{j, t-1}}
$$


where $j(=1, \ldots, m)$ denotes the mutual fund; $t$ denotes the quarter; $F_{j, t}$ is the total outflow experienced by mutual fund $j$ in quarter $t$; and $T A_{j, t-1}$ is the total assets of fund $j$ at the end of quarter $t$-1. Berger (2018) shows a possible selection bias behind fund-driven mispricing, as mutual funds are specialists and tend to invest in certain types of firms. To mitigate this concern that the mutual funds may be trading on private information, we exclude industry-specific funds, as in Edmans et al. (2012) and Eckbo et al. (2018).

We next aggregate the funds' outflows for each stock,

$$
\text { Outflow }_{i, t}=\sum_{j=1}^{m} \text { Outflow }_{j, t} \times \frac{\text { Shares }_{i, j,} \times \text { Price }_{i, t}}{\text { Volume }_{i, t}},
$$

where $i$ denotes the stock $i$; Price $_{i, t}$ denotes the stock price at the end of quarter $t$; Volume $_{i, t}$ denotes the stock's trading volume in quarter $t$; and Shares $_{i, j, t}$ is the number of shares that mutual fund $j$ holds in stock $i$.

We focus on large flows by only including funds for which the outflow (Outflow $\left.w_{j, t}\right)$ is equal to or greater than $5 \%$. Lastly, we sum the quarterly stock outflow (Outflow $\left.w_{i, t}\right)$ by calendar year, to accommodate yearly data on firm fundamentals and trade credit.

\subsection{Summary Statistics}

Figure I plots the year-by-year usage of external sources of finance for our baseline sample of firms from 1991 through 2014. Notably, although equity remains the major source of finance, trade credit (TC) accounts for a nontrivial proportion of external financing, close to that of long-term financial credit and exceeding that of short-term financial credit (see Panel A, Figure I). ${ }^{4}$ There

\footnotetext{
${ }^{4}$ We calculate the net issuance of short- and long-term debt based on the 3-year maturity cutoff. The construction of these two variables is presented in Appendix B.
} 
was also an upward trend in trade credit over our sample period (see Panel B, Figure I), except for the years 2001, 2008, and 2009. According to the descriptive statistics in Table I, the typical U.S. firm increased trade credit ( $d T C$ ) equivalent to $8.16 \%$ of its total assets, representing about $11 \%$ $(100 \times 0.53 /(1.99+0.31+2.52))$ of its total formal external finance (common equity issues plus financial debt).

[Insert Figure I about here]

The average value-to-price ratio $(U N)$ equals 0.95 , suggesting that, on average, a firm's stock is fairly valued by the stock market. Indeed, most firms exhibit a value-to-price ratio around one, as can be observed from the dashed curve in Figure II. Undervalued firms, defined as the group of firms present in the upper decile of the value-to-price ratio in year $t=0$, exhibit a rapid reversal in firm undervaluation, conforming to the view that stock mispricing is a short-lasting phenomenon. Moreover, as noted by Lee et al. (1999), since the implied risk premium could change over time, the value-to-price ratio is not necessarily equal to the theoretical cutoff of 1 , even in the absence of misvaluation. In the same way, a value-to-price ratio of more than 1 does not necessarily indicate undervaluation. Thus, it is important to highlight that we use this measure to draw inferences about whether a firm is underpriced relative to its counterparts or to another period when the firm is valued higher.

[Insert Table I about here]

[Insert Figure II about here]

The time trend in our undervaluation measure, as shown in Figure III, coincides with the conventional belief of the general market valuation over time. In particular, stock undervaluation is more severe during periods of recession. This general pattern applies to all sectors, but there 
also exist some sectorial differences. For instance, in the 2001 recession, undervaluation is more observable for firms operating in the manufacturing and oil, gas, and coal extraction industries. During the 2008-2009 crisis, firms operating in wholesale, retail, and health care industries were more affected.

[Insert Figure III about here]

To visualize the relationship between undervaluation and a firm's use of trade credit, in Figure IV we plot the year-by-year average usage (Panel A) and incremental issuance (Panel B) of trade credit by valuation group, classified by the value-to-price ratio. As illustrated in Panel A, the level of trade credit for the most undervalued firms, plotted in the solid black line, outperforms the other two valuation groups in most of the periods.

The relation between firm undervaluation and the incremental issuance of trade credit is more volatile (Panel B) and is also countercyclical, i.e., it strengthens during business expansions (e.g., the period from 2004-2006) and weakens during business recessions. This pattern differs from what the credit rationing literature suggests, i.e., that firms should increase their use of trade credit in periods of financial constraint. In particular, if undervaluation waves corroborate with credit rationing periods, we should expect to find that undervalued firms use more trade credit during business recessions. Conversely, this preliminary evidence suggests that trade credit may only work as a remedy for undervalued firms when there are no economy-wide shocks.

\section{[Insert Figure IV about here]}

Table II compares the use of trade credit across different stock valuation levels. Portfolios are constructed based on the uninstrumented undervaluation measure (i.e., the value-to-price ratio). We form the portfolios as follows: For each year, we sort firms into deciles according to their 
previous-fiscal-year-end value-to-price ratio. Firms in the highest decile comprise the most undervalued portfolio, those in the lowest decile comprise the most overvalued portfolio, and the remaining firms comprise the middle group. Time-series mean values of the uninstrumented undervaluation measure (UN), the level of trade credit, and the change in trade credit are reported for three portfolios, constructed based on the $10-90 \%$ undervaluation cutoffs. The differences among the portfolios are presented at the bottom of the table.

\section{[Insert Table II about here]}

In support of our first hypothesis, the univariate analysis shows that undervalued firms, in general, employ more trade credit than do overvalued firms, in both levels and changes. In Column (2), the most undervalued portfolio has $2.864 \%(\mathrm{t}=18.045)$ more $T C_{t}$ than does the most overvalued portfolio. Similarly, in Column (3), the most undervalued portfolio issues $0.145 \%(\mathrm{t}=$ 1.701) more $T C_{t}$ than does the most overvalued portfolio.

\section{Undervaluation and Trade Credit}

In this section, we formally test whether firms increase trade credit when they are temporarily undervalued by the financial market and whether undervalued firms substitute trade credit for short-term financial debt, which is known to be an alternative to trade credit due to its liquid nature.

\subsection{Empirical Specification}

We start by estimating model (7), without imposing any cash flow constraints, in the spirit of Rajan and Petersen (1997): ${ }^{5}$

${ }^{5}$ However, due to the fact that some data were not available, we were not able to apply the exact estimation strategy of Petersen and Rajan (1997). In that study, the researchers use NSSBF data and estimate the supply curve based on the fraction of goods offered on credit to firms. Specifically, they model a firm's accounts payable as a function of trade credit supply and demand 


$$
d T C=f(U N, \text { Control Variables, Firm FEs, Year FEs }),
$$

where $d T C$ represents the incremental use of trade credit and $U N$ represents the level of market undervaluation. Following Rajan and Petersen (1997), we control for firm size (Size), net leverage (NetLev), a dummy for no dividend payment $(N o D)$, a dummy for positive change in sales (PosSale), a dummy for negative change in sales (NegSale), a dummy for no sales (NoSale), firm age (Age), the square of firm age $\left(A g e^{2}\right)$, current ratio (CurrAsset), cash holdings (Cash), and net profit (Profit). As highlighted by Rajan and Petersen (1997), these variables reflect a firm's demand for credit in general and the demand for trade credit in particular. Firms with higher creditworthiness (e.g., larger and more mature firms with less outstanding debt), more growth opportunities (e.g., firms experiencing higher growth in sales), more short-term assets, and less cushion (such as cash) should exhibit a higher demand for trade credit. We incorporate firm and year fixed effects to rule out firm-specific heterogeneity and to isolate the influence of any economy-wide changes and cyclical effects. The slopes for $U N$ provide estimates of how market undervaluation pushes the issuance of trade credit away from the average. In particular, we expect the use of trade credit to increase with firm undervaluation.

To take a step further, we then analyze the use of trade credit relative to other sources of finance, especially short-term financial debt. To do so, we further employ a constrained regression approach, as in Fama and French (2012), in which a firm's financing decisions are simultaneously

factors, using a two-step approach. In their first step, they estimate the supply curve by regressing the fraction of goods offered on credit to a firm on the firm's characteristics. In their second step, they regress the firm's accounts payable on its trade credit supply, as proxied by the predicted value from the first regression along with a set of firm-level variables that they use to proxy for demand factors. Due to the fact that data on a firm's purchases on account are not available in Compustat, we adopt a single-step model, addressing the issue of trade credit supply separately in Section 5. 
determined in a unified framework. We extend this approach by integrating trade credit to distinguish the use of credit from a firm's suppliers from that of alternative lenders (i.e., the total of stock market investors and financial institutions). We apply Fama and French (2012) for this test, rather than Rajan and Petersen (1997), because a firm's financing decisions are simultaneously determined.

Specifically, a firm's use of funds supplied by the firm's suppliers/alternative lenders is modeled in Equation 8(a)/8(b) as a function of the firm's undervaluation $(U N)$, the cash flow constraint that the firm needs to realize at the time, and a set of control variables:

$$
\begin{gathered}
d T C=f(U N, \text { Cash Flow Constraint, Control Variables, Firm FEs, Year FEs }), \\
d F S=f(U N, \text { Cash Flow Constraint, Control Variables, Firm FEs, Year FEs }), \\
d T C_{i, t}+d F S_{i, t}=d A_{i, t}+D_{i, t}-Y_{i, t}-d M i s L_{i, t}+D D_{i, t-1} .
\end{gathered}
$$

For the cash flow constraint, as illustrated in Equation (8c), we impose the condition that the financing from trade credit $\left(d T C_{t}\right.$, the change in trade credit) and other formal funds $\left(d F S_{t}\right.$, the change in other formal sources of finance, including stocks issued and financial debt) equals the firm's demand for investment ( $d A_{t}$, the change in total asset), dividend distribution $\left(D_{t}\right)$, and the paying off of maturing debts $\left(D D_{t-1}\right.$, the current portion of long-term debt, measured as of the fiscal year $t-1)$, minus funds received from internal funds ( $Y_{t}$, earnings), and minus other miscellaneous borrowing $\left(d M i s L_{t}\right.$, the remainder of the firm's liabilities, mainly funds from internal capital markets). We also include long-term debt redemption $\left(D D 1_{t-1}\right)$ in the cash flow constraint to address the concern that firms need to regularly refinance their maturing debts to maintain an ongoing investment. The variables specified in the cash flow constraint (e.g., $d T C_{t}, d F S_{t}, d A_{t}, D_{t}$, 
$Y_{t}, d M i s L_{t}$, and $\left.D D 1_{t-1}\right)$ are all scaled by total assets at the beginning of fiscal year $t$ and multiplied by 100. (Details are given in Appendix B.)

This specification allows us to test the effect of undervaluation on the relative allocation of funds, instead of on the absolute allocation of funds. The slopes for $U N$ provide estimates of how market undervaluation pushes the split of external funding away from the average. We expect firm undervaluation to be positively related to trade credit in Equation (8a) and negatively related to other sources of finance in Equation (8b).

Moreover, imposing a cash flow constraint means that the estimates in the $d T C$ equation should always mirror the corresponding estimates in the $d F S$ equation. More precisely, the intercepts and residuals in the regressions (8a) and (8b) must add up to zero; the sums of the coefficients of $d A_{i, t}$, $D_{i, t}$, and $D D 1_{i, t-1}$ must add up to 1 ; and the slopes on $Y_{i, t}$ and $d M i s L_{i, t}$ must add up to -1 . For the extra variables (i.e., UN and the control variables), the coefficients must add up to $0 .{ }^{6}$

Further, to correct for any potential bias due to endogeneity in a firm's stock undervaluation, we use mutual fund outflow as an instrument and adopt the two-stage least squares (2SLS) approach. In the first stage regression, we use mutual fund outflow to predict the firm's undervaluation $(U N)$. Then, in the second stage, we plug in the estimated undervaluation $(\widehat{U N})$ to gauge the effect of undervaluation on trade credit.

The first-stage regression model that echoes specification (7) is illustrated in Equation (9), while the first-stage regression model that echoes specifications (8a) and (8b) is illustrated in Equation (10):

${ }^{6}$ Due to rounding errors, the sum of the estimated coefficients in the complementary regressions may not perfectly comply with the requirements of the cash flow constraint. 


$$
\begin{gathered}
\text { UN }=f(\text { Outflow, Control Variables, Firm FEs, Year FEs }), \\
\text { UN }=f(\text { Outflow, Cash Flow Constraint, Control Variables, Firm FEs, Year } \\
\text { FEs }),
\end{gathered}
$$

where Outflow represents the constructed instrumental variable mutual fund outflow. Note that the same set of control and cash flow variables are included as in the OLS regressions, i.e., Equation (9) for specification (7) and Equation (10) for specifications (8a) and (8b). The exogeneity of large capital outflows by mutual funds to a firm's fundamentals make these outflows a natural candidate to instrument for temporary undervaluation in the funds' holding stocks. The validity of such an approach can be seen in many other contexts; for example, there is strong evidence that takeover activities (Edmans et al., 2012; and Eckbo et al., 2018), seasoned equity offerings (Khan et al., 2012), and real decisions of firms (Hau and Lai, 2013) respond strongly to mutual fund induced price pressure.

\subsection{Empirical Results}

\subsubsection{Baseline Results}

We begin by examining whether firms increase their use of trade credit subsequent to stock market undervaluation, based on Equation (7). We gradually include control variables and add year fixed effects, given that the use of trade credit may be influenced by business cycles. Standard errors are clustered at the firm level.

The regression results, reported in Table III, are reassuring. In Panel A, the OLS estimates for the undervaluation measure $(U N)$ are statistically significant in all specifications. Consistent with our expectation that the use of trade credit is cyclical, adding year fixed effects in Column (4) 
absorbs the impact of firm undervaluation to some extent, compared with Column (3), but the estimate for $U N$ remains solid.

The results for the 2SLS regression, reported in Panel B, are even more reassuring. First, in accordance with the relevance condition, we find strong evidence that firm undervaluation is positively associated with mutual fund outflow (see Columns (1)-(4), Panel B). The weak instrument tests presented in the bottom rows (F-stats and Anderson-Rubin Wald stats) confirm the significance of the instrument, even when there are no other control variables. Furthermore, the endogeneity tests indicate that firm stock undervaluation is indeed endogenous, therefore there is a need for instrumental variables.

Second, the estimates for the instrumented undervaluation measure in the second-stage regression are all statistically significant and economically meaningful. Depending on the specification, a one-unit increase in $\widehat{U N}$ implies an increase of trade credit to assets by 1.51-3.04 percentage points, all else being equal. For the complete specification, a one-standard-deviation increase in a firm's undervaluation induces the firm to increase its use of trade credit by 2.20 (= estimated coefficient of $\widehat{U N} \times$ Standard deviation of $\widehat{U N}, 3.04 \times 0.7172$ ), all else being equal.

The estimates for the control variables are also in line with previous studies. On the one hand, undervalued firms tend to be smaller, have higher leverage, hold more liquidity assets, are more likely to experience negative sales, and are less likely to pay dividends, all else being equal. On the other hand, larger firms that encounter negative operational shocks also tend to obtain more trade credit. These firms have lower leverage, hold less cash, and are less likely to pay dividends.

[Insert Table III about here] 
Now that we have established baseline evidence in support of a positive relationship between stock undervaluation and trade credit, we next test whether there exists any substitution effect between trade credit vis-à-vis other formal sources of finance for undervalued firms. To this end, we follow Fama and French (2012) to estimate a system of two complementary regressions, as illustrated in Equations (8a) and (8b), by imposing the cash flow constraint (8c). We further separate negative earnings $(\mathrm{Neg} Y)$ from positive earnings $(\mathrm{Pos} Y)$, allowing for the possibility that the allocation of funds varies with the sign of the income shock. The slopes of $\widehat{U N}$ provide estimates for how stock undervaluation pushes the split of trade credit and other financing sources away from the average, in that the estimated effect reflects the relative distribution of funds rather than an absolute change driven by stock market undervaluation.

The regression results are displayed in Table IV (OLS regression results in Panel A and 2SLS regression results in Panel B). For the sake of simplicity, we only report the regression results for $d T C$, but one can easily infer the estimates in the $d F S$ regression, as the $d T C$ equation and the $d F S$ equation (8a) are complementary, given the cash flow constraint. For example, the estimates for undervaluation $(U N)$ in $d T C$ and $d F S$ must always add up to zero.

\section{[Insert Table IV about here]}

The estimates for the mutual fund outflow, according to Equation (10), as listed in Columns (1)-(4) in the top part of Panel B, Table IV, are again positive and significant. All the weak instrument and endogeneity tests are solid, confirming the idea that mutual fund outflow serves as a valid instrumental variable for firm undervaluation. Turning to the regression coefficients on the instrumental value-to-price ratio, we again find that trade credit responds positively to negative valuation shocks. 
As can be seen from the table, the results of imposing a cash flow constraint, as in Fama and French (2012), are not very different from those estimated following Rajan and Petersen (1997), in which cash flow constraints are not imposed. In the follow-up analyses of this section, we will focus on the Fama and French (2012) specification, as it allows us to tease out the substitution effect: Firms substitute trade credit for other conventional sources of finance in the presence of equity undervaluation.

\subsubsection{Firm Undervaluation and the Allocation Between Trade Credit and Short-Term Financial Debt}

We expect that when firms are searching for solutions to fill a liquidity shortage due to temporary undervaluation, trade credit will tend to act as a substitute for short-term financial debt (our second hypothesis). We formally test this proposition in Table V, using a system of two complementary equations for the allocation of financing among trade credit $(d T C)$ and short-term financial credit $(d S T D)$. This specification slightly changes the cash flow constraint, in the sense that dSTD needs to be netted out from $d F S$, while the remaining part of $d F S$ (equals $d F S-d S T D$ ) is moved to the right-hand side of the cash flow constraint equation.

The results are reassuring: The relation between $U N$ and $d T C$ is 0.16 (statistically significant at the $1 \%$ level) in the OLS regression and 2.96 (statistically significant at the 5\% level) in the 2SLS regression. These results demonstrate that trade credit, as an important source of liquidity, provides a buffer against temporarily unfavorable terms of accessing external capital.

Firms heavily dependent on external capital should find it more binding to finance their desired investment with external funds subsequent to stock market undervaluation. If so, we should see a rise in the sensitivity of the demand for trade credit to undervaluation with dependence on external finance. To test this prediction, we divide our sample into subsamples of firms with high and low 
levels of dependence on external finance (DEF, defined as the difference between a firm's capital expenditure and its cash flow from operations, divided by the cash flow from operations, as per Rajan and Zingales (1998)) and compare the effect of market undervaluation between the two groups of firms.

\section{[Insert Table $\mathrm{V}$ about here]}

We show that the undervaluation effect on trade credit varies fundamentally according to firms' dependence on external capital. Offsetting the price impact induced by market undervaluation plays a larger part in determining a firm's use of trade credit when dependence on external finance is high, relative to periods when dependence on external finance is low. It is worthwhile to note that the positive/negative association between firm undervaluation and trade credit/short-term financial debt is much more pronounced in firms that are highly dependent on external finance. In the OLS regressions, the average slope for $U N$ in high DEF firm-years is twice as big as that in low DEF firm-years. More importantly, the estimate for $U N$ is only statistically different from zero in high DEF firm-years in the 2SLS regressions. For example, the coefficient of $\widehat{U N}$ is 4.57 in the $d T C$ regression and -4.57 in the $d S T D$ regression for high DEF firms (Column (3)), which means that a one-standard-deviation increase in a firm's undervaluation pushes financing away from short-term financial debt toward trade credit by $3 \%(=4.57 \times 0.6566)$, all else being equal. The standard deviation of $\widehat{U N}$ is 0.6566 in high DEF firms.

\subsubsection{Firm Heterogeneity}

The results above demonstrate that trade credit, as an important source of liquidity, provides firms with a buffer against temporarily unfavorable stock market conditions and that undervalued firms tend to substitute trade credit for short-term financial debt. This section aims to examine the 
role of firm heterogeneity (i.e., bargaining power, dependence on external finance, and information environment).

For this purpose, we further partition our sample firms into two groups based on the 2-quantiles of firm size (Size, measured by log (total assets) of the firms), Rajan and Zingales's (1998) dependence on external finance (DEF, measured as the share of capital expenditure not financed by cash flow from operations), analyst forecast error (AFE, measured as the average absolute errors of all forecasts for target earnings, scaled by stock price), and analyst forecast dispersion (AFD, measured as the standard deviation in analyst forecasts). We replicate the exercise in Table III and Table IV for the subsamples, and our results, based on the terciles, convey a similar message. For the sake of brevity, we report regression coefficients only for the undervaluation measure. Note that the subsamples constructed using analyst forecast data are smaller, due to a lower coverage of analyst data from $\mathrm{I} / \mathrm{B} / \mathrm{E} / \mathrm{S}$. Because of this small sample size, we opt to report the 2-quantiles results; the subsample tests using terciles lead to saturated models and a lower statistical power, which may undermine the effect under investigation for these subsamples.

\section{[Insert Table VI about here]}

In general, Table VI reveals that the direct impact of undervaluation on trade credit is larger among larger firms with high dependence on external finance and high analyst forecast dispersion. Taken together, these results suggest that the role of stock market undervaluation in a firm's use of trade credit may operate in both the information asymmetry channel and the implicit equity stake channel. Note that although the OLS regression results based on analyst forecast error (AFE) show some discrepancies, the 2SLS regression results are again comparable to the other subsample analyses. 
Financial constraints on firms (commonly proxied by firm size) and market valuation are often highly correlated, which makes identifying the effect of undervaluation challenging. Our results on firms of different sizes rule out this concern, because if financial constraints were playing a dominant role, we should find the effect of undervaluation to be more prominent in small-size firms. Our findings confirm that undervaluation driven by mutual fund outflow is less susceptible to contagion by financial constraints, as trading-induced mispricing should be exogeneous to the fundamentals of the underlying firms.

\section{Undervaluation and Trade Credit: The Role of The Supplier Relationship}

In this section we test our third hypothesis, regarding the role of the supplier relationship. Our objectives are to determine whether the impact of undervaluation on trade credit is valid from both the demand and supply points of view and whether the impact of undervaluation varies with a firm's relationship to its suppliers.

\subsection{Empirical Specifications}

We consider suppliers to be lenders and track the use and provision of trade credit subsequent to the undervaluation of the suppliers' main customers. The form of trade credit analyzed is accounts payable ( $\left.d T C_{\text {customer }}\right)$ and accounts receivable $\left(d T C_{\text {supplier }}\right)$.

Using Compustat customer segment data, we manually match a supplier-customer sample. Following Garcia-Appendini and Montoriol-Garriga (2013), we run panel regressions for the customer's accounts payable to total assets and the supplier's accounts receivable to total sales, as illustrated in Equations (11) and (12). 


$$
\begin{gathered}
d T C_{\text {customer }}=f(\widehat{C U N}, \text { Customer's Characteristics, Supplier's Characteristics, } \\
\text { Customer-Supplier FEs, Year FEs }), \\
d T C_{\text {supplier }}=f(\widehat{C U N}, \text { Customer's Characteristics, Supplier's Characteristics, } \\
\text { Customer-Supplier FEs, Year FEs }),
\end{gathered}
$$

where $d T C_{\text {customer }}$ represents funds obtained from the firm's suppliers by their customers and $d T C_{\text {supplier }}$ represents funds owed to the suppliers by their customers. Our variable of interest is the instrumented customer's undervaluation ( $\widehat{C U N}$ ), which is predicted by regressing the customer's value-to-price ratio on the mutual fund outflow experienced by the customer and on the same set of exogenous variables as in Garcia-Appendini and Montoriol-Garriga, 2013. The richness of this matched dataset allows us to control for both supply-side and demand-side factors by including both the customer's and the supplier's characteristics. Further, including year and customer-supplier fixed effects helps to mitigate unobserved heterogeneity that may be related to economic cycles or to the initial status of customer-supplier relations. Standard errors are clustered at the firm level.

\subsection{Empirical Results}

As discussed above, we expect undervalued firms to increase their use of trade credit for two main reasons. First, compared to outside investors, suppliers that are economically linked to an undervalued firm have better knowledge of that firm and of the product market in which the firm (their customer) operates. Suppliers that work closely with a firm can thus derive more accurate expectations about the prospects of an undervalued firm and its true value. Second, suppliers have an economic interest in maintaining a good business relationship with their customers. Given the above, we expect that the characteristics of supplier relationships, including relationship proximity, 
bargaining power over the sale price, economic interaction, etc., explain the rise of trade credit in situations of firm undervaluation. To be more specific, we conjecture that 1) customers/suppliers with higher/lower bargaining power are more likely to obtain/extend trade credit; 2) long and repeated interactions reduce information asymmetry and lead suppliers to extend more trade credit.

\section{[Insert Table VII about here]}

Table VII reports the panel regression results of Equation (11). The estimated coefficients for $\widehat{C U N}$ in Columns (1) and (2) (with and without cash flow constraints) confirm our findings in Section 4, such that firms which are temporarily undervalued by the stock market obtain more trade credit. To further shed light on the operating channels, we next perform subsample tests based on the customer's size (measured by log (total assets)), their supplier pool (measured by the number of suppliers with which the customer is involved), and the length of the supplier relationship (measured by the years elapsed for each firm-supplier relationship).

The results in Columns (3)-(11) are two-fold. On the one hand, the positive relationship between trade credit and undervaluation is concentrated in the subset of firm-supplier pairs with longerterm relationships (see Column (11)) and is more pronounced in smaller customers (see Column (3)), in line with the information asymmetry argument. This result is intuitive, as the underlying assumption that a firm's own suppliers are better informed than the external markets is more believable for smaller firms with high information asymmetry and less believable for larger firms that are frequently examined by financial analysts. On the other hand, the effect is also more important in large customers with larger supplier pools (see Columns (5) and (8)), suggesting the prevalence of the implicit equity stake channel. Notably, the coefficient of $\widehat{C U N}$ in Column (8) is 34.10 , suggesting that a one-standard-deviation increase in the undervaluation of a customer with a large supplier pool is associated with an increase of $6.75 \%(=34.10 \times 0.1979)$ in the customer's 
accounts payable, all else being equal. Similarly, a one-standard-deviation increase in the undervaluation of a customer with a long-term relationship with its suppliers is associated with an increase of $3.52 \%(=14.22 \times 0.2473)$ in the customer's accounts payable. The standard deviation of $\widehat{C U N}$ in customers with large supplier pools and customers with long-term supplier relationships is 0.1979 and 0.2473 , respectively. Indeed, under some circumstances having a business relationship is comparable to owning stocks in a customer's firm, as pointed out by $\mathrm{Ng}$ et al. (1999). This should be especially true when dealing with big customers.

Adopting a supply perspective, Table VIII examines both trade credit and net trade credit and further shows evidence that suppliers extend more trade credit subsequent to their customer's undervaluation. Moreover, the more interaction a supplier has with the undervalued customer, the more trade credit the supplier is going to extend. The effect is also more valid for small suppliers with a smaller customer pool. Although the results on a supplier's extension of trade credit lose some statistical power, one caveat is that the Compustat customer segment data covers only the major customers of a firm, suggesting that the customers in our matched sample are mainly large firms.

[Insert Table VIII about here]

To conclude, the evidence shown in Tables VII and VIII as a whole can be interpreted in favor of the information asymmetry channel as well as the implicit equity stake channel: Suppliers interested in having a long-term relationship will extend trade credit at the request of important customers who are currently constrained by negative valuation shocks. 


\section{Additional Checks}

\subsection{Persistence}

The findings we have presented so far establish that a firm's use of trade credit increases upon the negative valuation of the firm. To interpret this result, we use the economic frameworks of information asymmetry and the implicit equity stake. We presume that suppliers have more information about a customer's creditworthiness than do other credit providers, and that sellers have an economic interest in maintaining good business relationships with their buyers. A supplying firm's stakeholders may agree to relax the limits on "credit" if they believe that their customer's valuation will be of short duration and that the customer's future performance will reward the relaxation. This interpretation suggests a short-lasting impact of firm undervaluation on trade credit, meaning that the increase in trade credit is only temporary.

\section{[Insert Table IX about here]}

Our results, as illustrated in Table IX, support this view: The coefficients on $\widehat{U N}$ in the 2SLS estimation have the expected sign only for one year; the estimated coefficient becomes insignificant in $t$-2 and $t$-3. This result echos Khan et al. (2012), who find that valuation shocks induced by mutual fund flows are transitory: Although stocks subject to large mutual fund buying pressure experience significantly positive abnormal returns in buying quarters, negative abnormal returns follow in subsequent quarters, as buying pressure subsides. Note that to ensure comparability, we use the same subsample for all the models in Table IX. Overall, our findings in this section support the view that trade credit plays a potentially important role in alleviating the shock of undervaluation. 


\subsection{Robustness}

In this section, we run a battery of robustness tests using various undervaluation measures and alternative empirical specifications, as well as separating crisis and non-crisis periods. Reassuringly, these tests, presented in Table X, lead to qualitatively similar results: When they are undervalued, firms substitute trade credit for conventional sources of finance.

\section{[Insert Table $\mathrm{X}$ about here]}

Note that to distinguish undervaluation from financial constraint, we did not include in our main analyses firms with negative terminal value (i.e., negative future cash flows at $t+3$ ), as these firms are most likely to be financially constrained. Including this group of firms in Column (1) shows qualitatively similar results.

To measure firm undervaluation, we used the value-to-price ratio. Prior research has generally used other accounting ratios, such as Q or the book-to-price ratio, to measure stock mispricing. It is important to note that these measures, although instructive, contain a component that reflects a firm's growth options, in addition to mispricing, if any. In Column (2) of Table X, we follow this literature and use the book-to-price ratio to measure undervaluation. The estimated coefficient on the intrumented book-to-price ratio has the expected sign, and the magnitude of the estimate is quite similar to that of our baseline model.

Column (3) of Table X computes valuation errors in a way similar to that developed by RhodesKropf, Robinson, and Viswanathan (2005). However, instead of decomposing the log market-tobook ratio, we decompose the log book-to-market ratio into a firm-specific error, a time-series sector error, and a long-run book-to-value component. We show a positive association of firmspecific error (the deviation of the firm's intrinsic value from its market pricing) with trade credit. 
This specification confirms our conjecture that firms have an incentive to increase trade credit when their stocks are valued lower than those of their peers.

We next address the concern that the perfect foresight model uses inputs gathered after the debt financing choices have been made, although the valuation is estimated beforehand. Instead we use analyst forecast data from $I / B / E / S$ to calculate ex ante misvaluation based on publicly available information. We then compute the intrinsic value of a firm using the median forecasted EPS. Convincingly, the estimated coefficients of the instrumented value-to-price ratio calculated based on the analyst forecast data, as shown in Column (4) of Table X, again have the expected positive sign. We do not use these specifications in our main analyses because, due to the scarce coverage of analyst data, using analyst forecast data would lead to a sharp reduction in our sample size.Using the perfect foresight model to estimate intrinsic value is also a common choice in previous studies, such as Lee et al. (1999), D’Mello and Shroff (2000), Dong et al. (2006), Elliott et al. (2008), and Warr et al. (2012).

Another concern is that the error terms are likely to be correlated when we run regressions of different sources of finance separately. Our regression framework (as illustrated in Equations (8a), (8b) and (8c)) mitigates this concern to some extent, because imposing the cash flow constraint means that the regressions in a system are complementary. To check the robustness of our model, we now consider the estimation of a seemingly unrelated regression (SUR) model in which we estimate a system of regression equations for stock issues, short-term financial debt, long-term financial debt, and trade credit on the same set of exogenous explanatory variables, including industry and year dummies, along with the value-to-price ratio (both uninstrumented and instrumented). The results are similar: $d T C$ is positively and significantly associated with $U N / \widehat{U N}$. For the sake of brevity, we report results only for the trade credit regression. 
We also test whether the relation between trade credit and stock undervaluation is true for net trade credit (defined as accounts payable minus accounts receivable) in Column (6). We find the expected sign, although the coefficient of the instrumented undervaluation measure, $\widehat{U N}$, is not significant in a statistical sense.

Finally, we examine whether the impact of undervaluation varies according to business cycles. To this end, we split our sample into two sets of firm-year observations: normal periods vs. crisis periods. We refer to the NBER-based Recession Indicators to define the crisis periods. Specifically, we consider a firm to be in a crisis situation if at least three recession months fall within the firm's fiscal year. Our results, reported in Columns (7) and (8) of Table X, show that the relation between firm undervaluation and trade credit is positive in both periods and that the magnitude appears to be bigger during crisis periods. The 2SLS regression results show that the effect of undervaluation on trade credit is concentrated in non-crisis periods. The insignificance of the coefficient of $\widehat{U N}$ may be explained by the fact that suppliers are also faced with financial constraints during the crises, and therefore can no longer lend to their undervalued customers. Notably, this robustness check echoes the pattern illustrated in Figure II. Taken together, these robustness checks confirm that the undervaluation effect revealed using our IV approach is likely to be orthogonal to the effect of the firm's financial constraints.

\section{Concluding Remarks}

In this paper, we show that firms have an incentive to switch to trade credit when their stock is undervalued. Rather than taking on expensive stock and risky financial debts, particularly shortterm financial debts, a firm uses more trade credit. Moreover, we find that the effect of undervaluation on a firm's choice to use trade credit varies with firm size, dependence on external 
finance, and information asymmetry. Further, our analyses using a matched supplier-customer sample show that suppliers provide more trade credit to their undervalued customers. On the one hand, this effect is concentrated among small customers with long-term relationships with their suppliers, supporting the idea that more frequent interactions help suppliers hold superior information about their customers' prospects. On the other hand, consistent with the argument that suppliers have an implicit equity stake in their customers' firms, we find that big customers with a large supplier pool are more likely to receive trade credit, and small suppliers are more likely to extend it, when the customer is temporarily undervalued by the stock market. Finally, we show that the effect of undervaluation on the use of trade credit is temporary (i.e., only valid for one year). In other words, trade credit acts as bridge financing in undervalued markets. Overall, our findings support the view that trade credit plays a potentially important role in alleviating the shock of undervaluation, and reinforce the ideas that supplying firms hold superior information about their customers' prospects and have an implicit equity stake in those firms.

To address the potential for endogeneity bias, we use mutual fund flow-driven price pressure to instrument for a firm's stock undervaluation. First, in accordance with the relevance condition, the nature of mutual funds (e.g., highly transparent, with restrictions on short selling other securities, etc.) gives a fund experiencing a sudden withdrawal of outside capital no choice but to sell its holdings quickly, which imposes a temporary price pressure on its portfolio firms. Second, this price pressure represents an exogeneous variation in a firm's stock price, as the fund-level flow is less likely to be correlated with the individual stock's fundamentals or with the firm's decisions. Indeed, the previous literature has provided evidence that corporate policies, e.g., takeover activities (Edmans et al., 2012; Eckbo et al., 2018), seasoned equity offerings and insider sales (Khan et al., 2012), and corporate investment and employment (Hau and Lai, 2013) all 
respond strongly to mutual fund-induced price pressure. Our paper therefore falls in with this line of literature using mutual fund flows as an instrument for stock mispricing.

Aside from a direct test of how stock undervaluation affects trade credit in absolute terms, we also employ the constrained regression approach in Fama and French (2012), which allows us to test for the role of undervaluation in relative terms, i.e., the choice of trade credit versus short-term financial debt. Our findings remain robust if we consider alternative misvaluation measures, use alternative estimation methods, and specify ex ante publicly available information at the time of issuance.

Our paper has important managerial and policy implications. As mentioned above, trade credit is an essential source of short-term financing for U.S. firms. Despite its commercial importance, there remains a large gap between academia and industry in understanding why selling firms (i.e., suppliers) would act as financial intermediaries and under which circumstances their customers would prefer trade credit, which is known to be an expensive form of finance if not repaid quickly. Recently, some light has been shed on this problem from the point of view of liquidity provision (Cuñat, 2007; Garcia-Appendini and Montoriol-Garriga, 2013). Our paper adds to this discussion by highlighting the role of capital market imperfections. In particular, we show that stock market undervaluation can trigger a sizable use of trade credit in the corporate sector. Although this provides liquidity insurance to undervalued firms, it may also impose a severe burden on the banking sector and may exaggerate a liquidity crisis, as shown by Garcia-Appendini and Montoriol-Garriga (2013), if suppliers then draw a large amount of credit lines from their banks to support their customers. The use of trade credit is therefore a double-edged sword, which deserves a closer examination of all the relevant aspects facing policy makers to avoid misallocation of resources. 


\section{Appendix A. Variable Definitions ${ }^{7}$}

\begin{tabular}{|c|c|c|}
\hline Variables & Abbreviation & Measurement \\
\hline Undervaluation & $U N_{t-1}$ & $\begin{array}{l}\text { Undervaluation measured by the intrinsic value at the end of fiscal } \\
\text { year } \mathrm{t}-1 \text {, divided by the CRSP closing price at the end of calendar } \\
\text { year } \mathrm{t}-1 \text {. Intrinsic value is estimated in the framework of the residual } \\
\text { income model, assuming perfect foresight of managers. }\end{array}$ \\
\hline $\begin{array}{l}\text { Mutual Fund } \\
\text { Outflow }\end{array}$ & Outflow $_{t-1}$ & $\begin{array}{l}\text { Mutual fund outflow, similar to that of Edmans et al. (2012), being } \\
\text { the weighted summation of the total outflow experienced by each } \\
\text { mutual fund that holds stock } i \text {. The summation is only over funds } \\
\text { whose outflow is equal to or greater than } 5 \% \text {. }\end{array}$ \\
\hline Trade Credit & $d T C_{t}$ & $\begin{array}{l}\text { Change in trade credit during fiscal year } \mathrm{t} \text {, scaled by total assets at } \\
\text { year } \mathrm{t}-1 \text { and multiplied by } 100 \text {. }\end{array}$ \\
\hline $\begin{array}{l}\text { Formal Sources of } \\
\text { Financing }\end{array}$ & $d F S_{t}$ & $\begin{array}{l}\text { Change in formal sources of finance (i.e., stocks, short-term and } \\
\text { long-term financial debts) during fiscal year t, scaled by total assets } \\
\text { at year t- } 1 \text { and multiplied by } 100 \text {. }\end{array}$ \\
\hline Stocks Issued & $d S_{t}$ & $\begin{array}{l}\text { Change in common equity plus dividends, minus earnings, during } \\
\text { fiscal year } t \text {, scaled by total assets at year } t-1 \text { and multiplied by } 100 \text {. }\end{array}$ \\
\hline Change in Short- & $d S T D_{t}$ & Net short-term debt issuance during fiscal year t. \\
\hline Change in Long- & $d L T D_{t}$ & Net long-term debt issuance during fiscal year $\mathrm{t}$. \\
\hline $\begin{array}{l}\text { Change in } \\
\text { Miscellaneous }\end{array}$ & $d M i s L_{t}$ & $\begin{array}{l}\text { Change in miscellaneous liabilities (total liabilities net of total } \\
\text { financial debt and trade credit) during fiscal year t. }\end{array}$ \\
\hline Long-term Debt & $D D 1_{t-1}$ & Long-term debt due in one year at the end of fiscal year $\mathrm{t}-1$. \\
\hline Change in Assets & $d A_{t}$ & $\begin{array}{l}\text { Change in total assets during fiscal year } \mathrm{t} \text {, scaled by total assets at } \\
\text { year } \mathrm{t}-1 \text { and multiplied by } 100 \text {. }\end{array}$ \\
\hline Earnings & $Y_{t}$ & $\begin{array}{l}\text { Income before extraordinary items available for common } \\
\text { stockholders, plus extraordinary items and discontinued operations, } \\
\text { during fiscal year t. }\end{array}$ \\
\hline Negative Earnings & $\mathrm{Neg} Y_{t}$ & Earnings during fiscal year $t$ if $Y_{t}$ is negative. \\
\hline Positive Earnings & $\operatorname{Pos} Y_{t}$ & Earnings during fiscal year $t$ if $\mathrm{Y}_{\mathrm{t}}$ is positive. \\
\hline Dividends & $D_{t}$ & $\begin{array}{l}\text { Dividend per share of stock at the end of fiscal year } t \text {, multiplied by } \\
\text { common shares outstanding at the end of calendar year } t \text {. }\end{array}$ \\
\hline $\begin{array}{l}\text { No Dividends } \\
\text { Dummy }\end{array}$ & $N o D_{t}$ & $\begin{array}{l}\text { A dummy variable that takes the value of one if a firm does not pay } \\
\text { dividends during fiscal year } t \text {, and } 0 \text { otherwise. }\end{array}$ \\
\hline Firm Size & Size $_{t-1}$ & $\begin{array}{l}\text { The log-transformed book value of assets at the beginning of fiscal } \\
\text { year t. }\end{array}$ \\
\hline Net Leverage & NetLev $v_{t-1}$ & $\begin{array}{l}\text { The ratio of a firm's total debt outstanding, excluding cash, to the } \\
\text { book value of total assets at the beginning of fiscal year t. }\end{array}$ \\
\hline
\end{tabular}

${ }^{7} d A_{t}, d S_{t}, d L_{t}, d T C_{t}, d F D_{t}, d S T D_{t}, d L T D_{t}, d M i s L_{t}, D D 1_{t-1}, D_{t}, Y_{t}, N e g Y_{t}$, and $\operatorname{Pos} Y_{t}$ are scaled by total assets at the beginning of fiscal year $t$ and multiplied by 100 . 


\section{Appendix A - continued}

\begin{tabular}{|c|c|c|}
\hline Variables & Abbreviation & Measurement \\
\hline $\begin{array}{l}\text { Positive Change in } \\
\text { Sales }\end{array}$ & PosSale $_{t-1}$ & $\begin{array}{l}\text { Firm's positive change in sales to the book value of total assets, and } \\
0 \text { otherwise at the beginning of fiscal year } t \text {. }\end{array}$ \\
\hline $\begin{array}{l}\text { Negative Change } \\
\text { in Sales }\end{array}$ & NegSale $_{t-1}$ & $\begin{array}{l}\text { Firm's negative change in sales to the book value of total assets, and } \\
0 \text { otherwise at the beginning of fiscal year t. }\end{array}$ \\
\hline No Sales Dummy & NoSale $_{t-1}$ & $\begin{array}{l}\text { A dummy variable that takes the value of one if sales are missing for } \\
\text { a firm during fiscal year } t \text {, and } 0 \text { otherwise at the beginning of fiscal } \\
\text { year } t \text {. }\end{array}$ \\
\hline Sales Growth & GrowthSale $_{t-1}$ & $\begin{array}{l}\text { Change in sales to the book value of total assets at the beginning of } \\
\text { fiscal year } t \text {. }\end{array}$ \\
\hline Firm Age & $A g e_{t-1}$ & $\begin{array}{l}\text { The log-transformed firm age at the end of fiscal year t. Firm age is } \\
\text { defined as the number of years elapsed since the first year that a firm } \\
\text { appeared in CRSP at the beginning of fiscal year } t \text {. }\end{array}$ \\
\hline Firm Age $^{2}$ & $A g e_{t-1}^{2}$ & $\begin{array}{l}\text { The squared log-transformed firm age at the beginning of fiscal year } \\
\text { t. }\end{array}$ \\
\hline Current Assets & CurrAsset $_{t-1}$ & $\begin{array}{l}\text { The ratio of a firm's current assets, excluding cash, to total assets at } \\
\text { the beginning of fiscal year t. }\end{array}$ \\
\hline Cash & $\operatorname{Cash}_{t-1}$ & $\begin{array}{l}\text { The ratio of a firm's cash and short-term investments to total assets } \\
\text { at the beginning of fiscal year t. }\end{array}$ \\
\hline Leverage & $\operatorname{Lev}_{t-1}$ & $\begin{array}{l}\text { The ratio of a firm's total debt outstanding to the book value of total } \\
\text { assets at the beginning of fiscal year t. }\end{array}$ \\
\hline Net Profit & Profit $_{t-1}$ & $\begin{array}{l}\text { The ratio of a firm's net profit to total assets at the beginning of fiscal } \\
\text { year t. }\end{array}$ \\
\hline
\end{tabular}




\section{Appendix B. Net Issuance of Short- and Long-term Debt}

We assume that in year $t+1$ the current portion of long-term debt in year $t$ is completely refinanced, and debts with maturities of $n$ years $(n=2,3,4,5)$ change their accounting identity to debts maturing in n-1 years. That is, long-term debt due in the $1^{\text {st }}$ year is paid off in the upcoming year, and debt due in the $2^{\text {nd }}$ year turns into debt due in 1 year on the firm's balance sheet, and so on. The accounting identities for the net issuance of debt with various maturities are written as:

$$
\begin{gathered}
d S T D_{t}=d D L C_{t}-d D D 1_{t} \\
d D D 1_{t}=D D 1_{t}-D D 2_{t-1} \\
d D D 2_{t}=D D 2_{t}-D D 3_{t-1} \\
d D D 3_{t}=D D 3_{t}-D D 4_{t-1} \\
d D D 4_{t}=D D 4_{t}-D D 5_{t-1} \\
d D D 5_{t}=D D 5_{t}+D D 6+_{t}-D D 6+_{t-1},
\end{gathered}
$$

where $d S T D_{t}$ represents the net change in short-term debt during fiscal year t, excluding the current portion of long-term debt; $d D D 1_{t}, d D D 2_{t}, d D D 3_{t}, d D D 4_{t}$, and $d D D 5+_{t}$ represent net changes in long-term debts which mature in one, two, three, four, and beyond five years; $D L C$ is the Compustat data item for financial debt in current liabilities; $D D 1, D D 2, D D 3, D D 4$, and $D D 5$ are long-term debts payable in one, two, three, four, and five years; and $D D 6+$ is long-term debt maturing in more than 6 years, constructed as DLTT (long-term debt maturing beyond one year) minus the sum of $D D 2, D D 3, D D 4$, and $D D 5$. 
Net issuance of debts with maturities inferior or superior to $\mathrm{x}(\mathrm{x}=1,2,3,4)$ years can be easily constructed by adding up the related items. For instance, for the one-year maturity cutoff, the net change in short-term debt $(d S T D)$ is the sum of $d S T D$ and $d D D 1$, and the net change in long-term debt $(d L T D)$ is the sum of $d D D 2, d D D 3, d D D 4$, and $d D D 5+$. 


\section{Appendix C. Rhodes-Kropf, Robinson, and Viswanathan's (2005) Valuation Errors}

One of our robustness checks, presented in Column (3), Table X, computes valuation errors in a way similar to that developed by Rhodes-Kropf, Robinson, and Viswanathan (2005). However, instead of decomposing the log market-to-book ratio, we decompose the log book-to-market ratio into a firm-specific error, a time-series sector error, and a long-run book-to-value component,

$$
b_{i, t}-m_{i, t}=v\left(\theta_{i, t} ; \alpha_{j, t}\right)-m_{i, t}+v\left(\theta_{i, t} ; \alpha_{j}\right)-v\left(\theta_{i, t} ; \alpha_{j, t}\right)+b_{i, t}-v\left(\theta_{i, t} ; \alpha_{j}\right),
$$

where $v\left(\theta_{i, t} ; \alpha\right)$ expresses the fundamental value based on a vector of multiple $\alpha, v\left(\theta_{i, t} ; \alpha_{j, t}\right)$ is the time-t fundamental value conditional on sector $j$ 's valuation, and $v\left(\theta_{i, t} ; \alpha_{j}\right)$ is sector $j$ 's timeinvariant valuation. Estimating $v\left(\theta_{i, t} ; \alpha_{j, t}\right)$ and $v\left(\theta_{i, t} ; \alpha_{j}\right)$, as in Rhodes-Kropf et al. (2005), we run valuation regressions for each of the Fama-French 12 industries. Specifically, we regress market equity on book equity, positive net income, the absolute value of negative net income, and book leverage, all expressed as natural logs. Then, using the obtained estimates and time-series average values of these estimates, we estimate the values for $v\left(\theta_{i, t} ; \alpha_{j, t}\right)$ and $v\left(\theta_{i, t} ; \alpha_{j}\right)$, respectively. 


\section{References}

Aktas, N., Croci, E., Petmezas, D., 2015. Is working capital management value-enhancing? Evidence from firm performance and investments. Journal of Corporate Finance 30, 98-113.

Aktas, N., De Bodt, E., Lobez, F., Statnik, J.C., 2012. The information content of trade credit. Journal of Banking and Finance 36, 1402-1413.

Alti, A., 2006. How persistent is the impact of market timing on capital structure? Journal of Finance 61, 1681-1710.

Atanasova, C., 2012. How do firms choose between intermediary and supplier finance? Financial Management 41, 207-228.

Baker, M., 2009. Capital market-driven corporate finance. Annual Review of Financial Economics $1,181-205$.

Baker, M., Greenwood, R., Wurgler, J., 2003. The maturity of debt issues and predictable variation in bond returns. Journal of Financial Economics 70, 261-291.

Baker, M., Stein, J.C., Wurgler, J., 2003. When does the market matter? Stock prices and the investment of equity-dependent firms. Quarterly Journal of Economics 118, 969-1005.

Baker, M., Ruback, R.S., Wurgler J., 2007. Behavioral corporate finance: An updated survey. In: Eckbo, B. E. (Ed.), Handbook in Corporate Finance, Vol. 1. Elsevier Press.

Baker, M., Wurgler, J., 2002. Market timing and capital structure. Journal of Finance 57, 1-32. 
Baker, M., Wurgler J., 2013. Behavioral corporate finance: An updated survey. In: Constantinides, G.M., Harris, M., Stulz, R.M. (Eds.), Handbook of the Economics of Finance, Vol. 2A. Elsevier Press.

Bancel, F., Mittoo, U.R., 2004. Cross-country determinants of capital structure choice: Survey of European firms. Financial Management 33, 103-132.

Barry, C.B., Mann, S.C., Mihov, V.T., Rodriguez, M., 2008. Corporate debt issuance and the historical level of interest rates. Financial Management 37, 413-430.

Ben-David, I., Drake, M.S., Roulstone, D.T., 2015. Acquirer valuation and acquisition decisions: Identifying mispricing using short interest. Journal of Financial and Quantitative Analysis $50,1-32$.

Berger, E., 2018. Does stock mispricing drive firm policies? Mutual fund fire sales and selection bias. Working paper, Cornell University.

Biais, B., Gollier, C., 1997. Trade credit and credit rationing. Review of Financial Studies 10, $903-$ 937.

Casey, E., O’Toole, C.M., 2014. Bank lending constraints, trade credit, and alternative financing during the financial crisis: Evidence from European SMEs. Journal of Corporate Finance 27, 173-193.

Choi, W.G., Kim, Y., 2005. Trade credit and the effect of macro-financial shocks: Evidence from U.S. panel data. Journal of Financial and Quantitative Analysis 50, 1-32. 
Coval, J., Stafford, E., 2007. Asset fire sales (and purchases) in equity markets. Journal of Financial Economics 86, 479-512.

Cuñat, V., 2007. Trade credit: Suppliers as debt collectors and insurance providers. Review of Financial Studies 20, 491-527.

Daripa, A., Nilsen, J., 2011. Ensuring sales: A theory of inter-firm credit. American Economic Journal: Microeconomics 3, 245-279.

D'Mello, R., Shroff, P.K., 2000. Equity undervaluation and decisions related to repurchase tender offers: An empirical investigation. Journal of Finance 55, 2399-2424.

Dittmar, A., Field, L.C., 2015. Can managers time the market? Evidence using repurchase price data. Journal of Financial Economics, 115, 261-282.

Dong, M., Hirshleifer, D., Teoh, S.H., 2012. Overvalued equity and financing decisions. Review of Financial Studies 25, 3645-3683.

Eckbo, B.E., Makaew, T., Thorburn, K.S., 2018, Are stock-financed takeovers opportunistic? Journal of Financial Economics 128, 443-465.

Edmans, A., Goldstein I., Jiang W., 2012, The real effects of financial markets: The impact of prices on takeovers. Journal of Finance 67, 933-971.

Elliott, W.B., Koeter-Kant, J., Warr, R.S., 2008. Market timing and the debt-equity choice. Journal of Financial Intermediation 17, 175-197. 
Fama, E.F., Macbeth, J.D., 1973. Risk, return, and equilibrium: Empirical tests. Journal of Political Economy 81, 607-636.

Fama, E.F., French, K.R., 2012. Capital structure choices. Critical Finance Review 1, 59-101.

Faulkender, M., Petersen, M.A., 2006. Does the source of capital affect capital structure? Review of Financial Studies 19, 45-79.

Ferrando, A., Mulier, K., 2013. Do firms use the trade credit channel to manage growth? Journal of Banking and Finance 37, 3035-3046.

Flannery, M.J., 1986. Asymmetric information and risky debt maturity choice. Journal of Finance 41, 19-37.

Frankel, R., Lee, C., 1998. Accounting valuation, market expectation, and cross-sectional stock returns. Journal of Accounting and Economics 25, 283-319.

Garcia-Appendini, E., Montoriol-Garriga, J., 2013. Firms as liquidity providers: Evidence from the 2007-2008 financial crisis. Journal of Financial Economics 109, 272-291.

Giannetti, M., Burkart, M., Ellingsen, T., 2011. What you sell is what you lend? Explaining trade credit contracts. Review of Financial Studies 24, 1261-1298.

Graham, J.R., Harvey, C.R., 2001. The theory and practice of corporate finance: Evidence from the field. Journal of Financial Economics 60, 186-243.

Guariglia, A., Mateut, S., 2006. Credit channel, trade credit channel, and inventory investment: Evidence from a panel of UK firms. Journal of Banking and Finance 30, 2835-2856. 
Hadlock, C.J., Pierce, J.R., 2010. New evidence on measuring financial constraints: Moving beyond the KZ index. Review of Financial Studies 23, 1909-1940.

Harford, J., Martos-Vila, M., Rhodes-Kropf, M., 2015. Corporate financial policies in misvalued credit markets. Working paper, Harvard Business School.

Hau, H., Lai, S., 2013. Real effects of stock underpricing. Journal of Financial Economics 108, 392-408.

Hovakimian, A., 2004. The role of target leverage in security issues and repurchases. Journal of Business 77, 1041-1072.

Hovakimian, A., 2006. Are observed capital structures determined by equity market timing? Journal of Finance 41, 221-43.

Hovakimian, A., Opler, T., Titman, S., 2001. The debt-equity choice. Journal of Financial and Quantitative Analysis 36, 1-24.

Jensen, M.C., 2005. Agency cost of overvalued equity. Financial Management 34, 5-19.

Khan, M., Kogan, L., Serafeim, G., 2012. Mutual fund trading pressure: Firm-level stock price impact and timing of SEOs. Journal of Finance 67, 1371-1395.La Porta, R., Lopez-DeSilanes, F., Shleifer, A., Vishny, R.W., 1997. Legal determinants of external finance. Journal of Finance 52, 1131-1150.

Lee, C., Myers, J., Swaminathan, B., 1999. What is the intrinsic value of the Dow? Journal of Finance 54, 1693-1741. 
Marsh, P., 1982. The choice between equity and debt: An empirical study. Journal of Finance 37, 121-144.

Mateut, S., Bougheas, S., Mizen, P., 2006. Trade credit, bank lending, and monetary policy transmission. European Economic Review 50, 603-629.

Mian, S., Smith, C., 1992. Accounts receivable management. Journal of Finance 47, 169-200.

Murfin, J., Njoroge, K., 2015. The implicit costs of trade credit borrowing by large firms. Review of Financial Studies 28, 112-145.

Myers, S.C., Majluf, N.S., 1984. Corporate financing and investment decisions when firms have information that investors do not have. Journal of Financial Economics 13, 187-221.

Newey, W.K., West, K.D., 1987. A simple, positive semi-definite, heteroskedasticity and autocorrelation consistent covariance matrix. Econometrica 55, 703-708.

Ng, C.K., Smith, J.K., Smith, R.L., 1999. Evidence on the determinants of credit terms used in interfirm trade. Journal of Finance 54, 1109-1129.

Petersen, M.A. and Rajan, R.G., 1997. Trade credit: theories and evidence. Review of Financial Studies 10, 661-691.

Polk, C., Sapienza, P., 2009. The stock market and corporate investment: A test of catering theory. Review of Financial Studies 21, 187-217.

Rajan, R. G. and Zingales, L., 1998. Financial dependence and growth. American Economic Review 88, 559-586. 
Rhodes-Kropf, M., Robinson, D.T., Viswanathan, S., 2005. Valuation waves and merger activity: The empirical evidence. Journal of Financial Economics 77, 561-603.

Shleifer, A., 2000. Inefficient markets: An introduction to behavioral finance. Oxford University Press.

Shenoy, J., Williams, R., 2017. Trade credit and the joint effects of supplier and customer financial characteristics. Journal of Financial Intermediation 29, 68-80.

Smith, J., 1987. Trade credit and informational asymmetry. Journal of Finance 42, 863-72.

Sufi, A., 2007. Information asymmetry and financing arrangements: Evidence from syndicated loans. Journal of Finance 62, 629-668.

Sufi, A., 2009. The real effects of debt certification: Evidence from the introduction of bank loan ratings. Review of Financial Studies 22, 1659-1691.

Tsetsekos, G.P., Kaufman, D.J., Gitman, L.J., 1991. A survey of stock repurchase motivations and practices of major U.S. corporations. Journal of Applied Business Research 7, 15-20.

Warr, R.S., Elliott, W.B., Koëter-Kant, J., Öztekin, Ö., 2012. Equity mispricing and leverage adjustment costs. Journal of Financial and Quantitative Analysis 47, 589-616.

Warusawitharana, M., Whited, T.M., 2016. Equity market misvaluation, financing, and investment. Review of Financial Studies 29, 603-654.

Wilson, N., Summers, B., 2002. Trade credit terms offered by small firms: Survey evidence and empirical analysis. Journal of Business Finance and Accounting 29, 317-351. 


\section{Figure I}

\section{External Sources of Finance for Non-Financial U.S. firms from 1991 through 2014}

This figure shows the year-by-year trade credit (i.e., accounts payable), short-term and long-term financial credits, and stocks. In Panel A, financing sources are scaled by total assets and multiplied by 100. Panel B calculates the change in each financing source, scaled by total assets and multiplied by 100 . The sample is drawn from the CRSP and Compustat Merged database for non-financial U.S. firms over the period from 1992 through 2014.

Panel A: Levels in Financing Sources

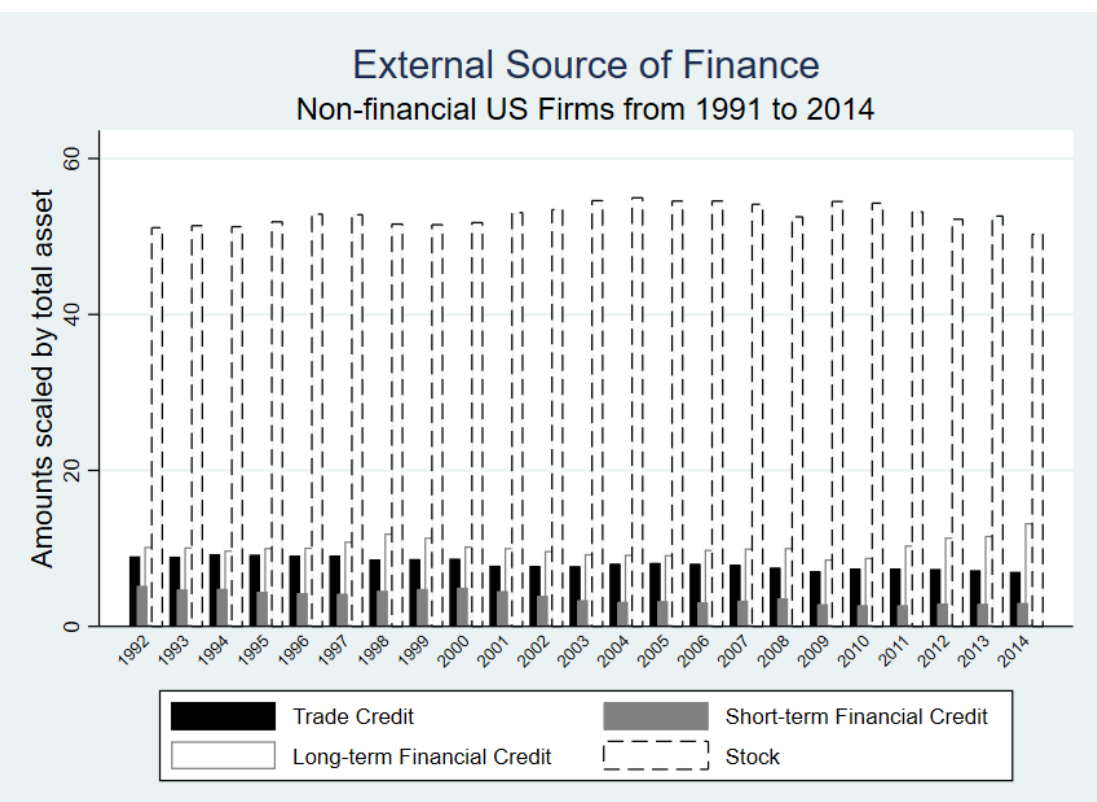

Panel B: Changes in Financing Sources

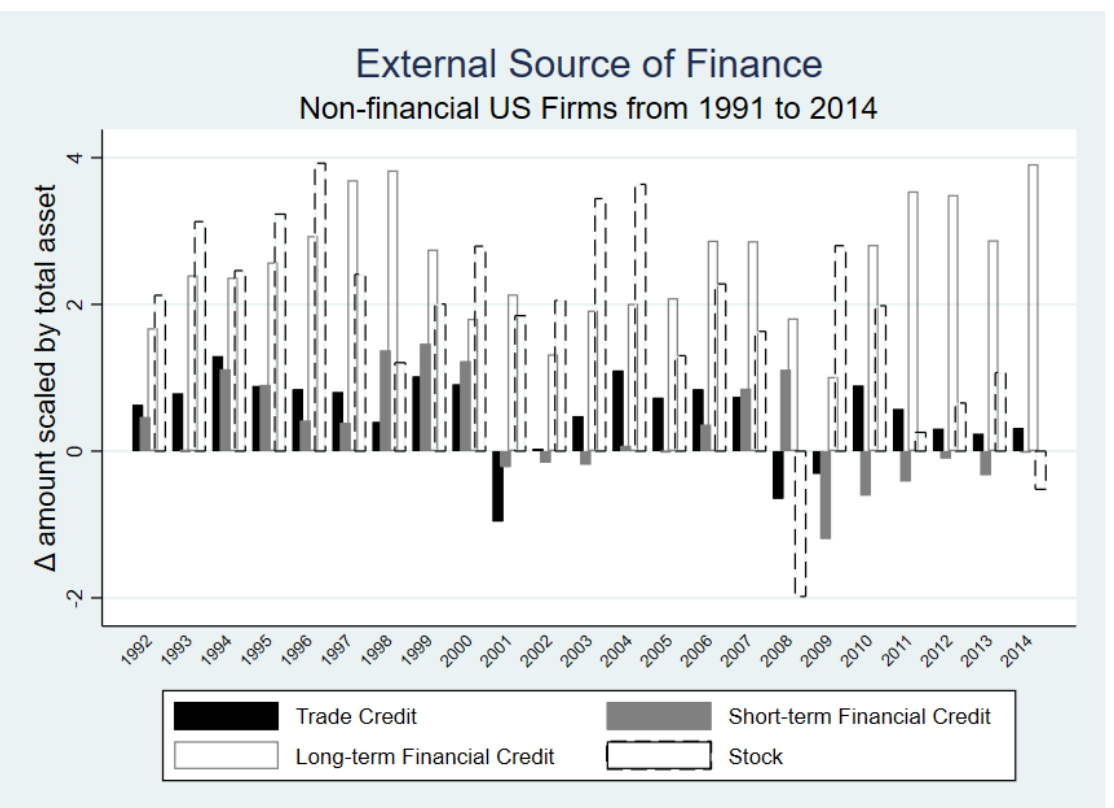




\section{Figure II}

\section{Firm Undervaluation in Event Time}

This figure exhibits the evolution of firm undervaluation from year $t-3$ to $t+3$ for two portfolios (undervalued firms versus the rest of the firms) constructed based on firms' value-to-price ratio. Undervalued firms are firms in the upper decile of the uninstrumented value-to-price ratio. Event time 0 denotes the portfolio formation year. Event time s, plotted along the $\mathrm{x}$ axis, denotes the sth year subsequent to the portfolio formation year $(\mathrm{s}=-3,-2,-1,1,2,3)$. The solid curve represents the average value-to-price ratio for undervalued firms and the dashed curve represents the average value-to-price ratio for the rest of the firms. The sample is drawn from the CRSP and Compustat Merged database for non-financial U.S. firms over the period from 1992 through 2014.

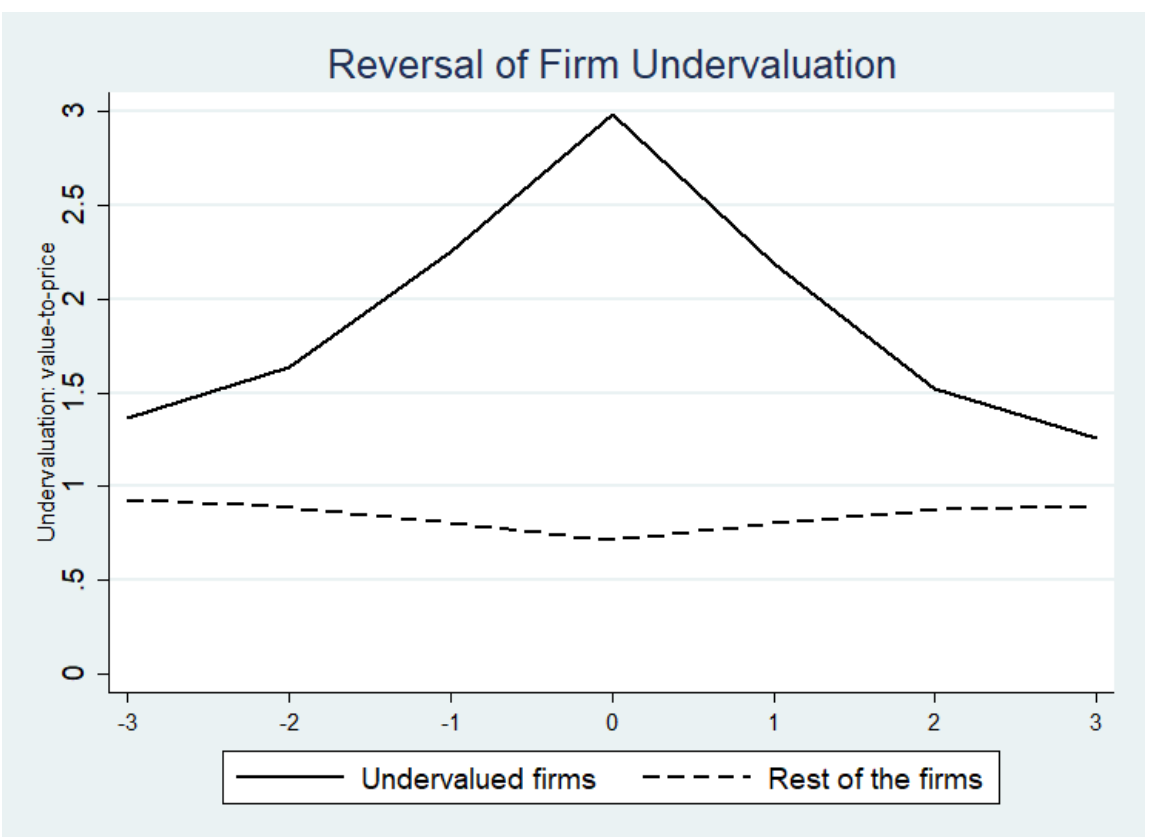




\section{Figure III}

\section{Time Trend of Firm Undervaluation}

This figure shows the time trend in our firm undervaluation measure, i.e., the value-to-price ratio. Panel A plots the the mean value-to-price ratio over time for all firms in our sample. Panel B plots the time trend by industry, according to the Fama-French 10 industry classification. The sample is drawn from the CRSP and Compustat Merged database for non-financial U.S. firms over the period from 1992 through 2014.

\section{Panel A: Overall}

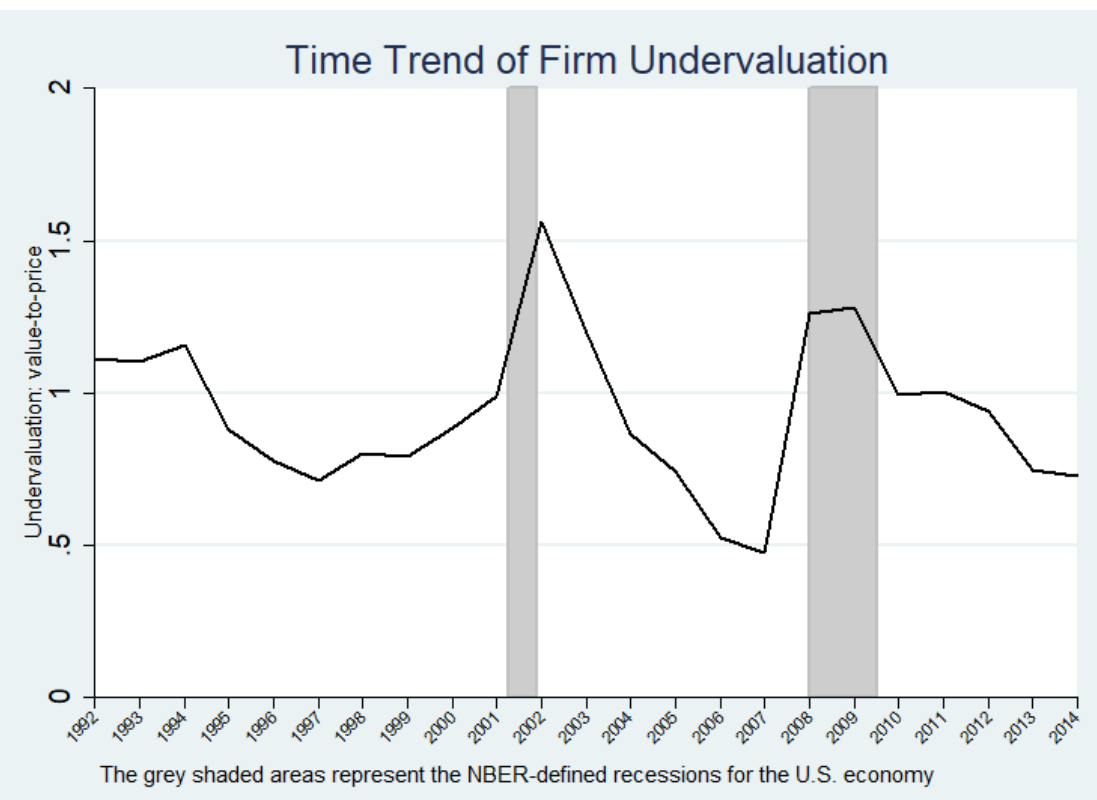

Panel B: By Industry

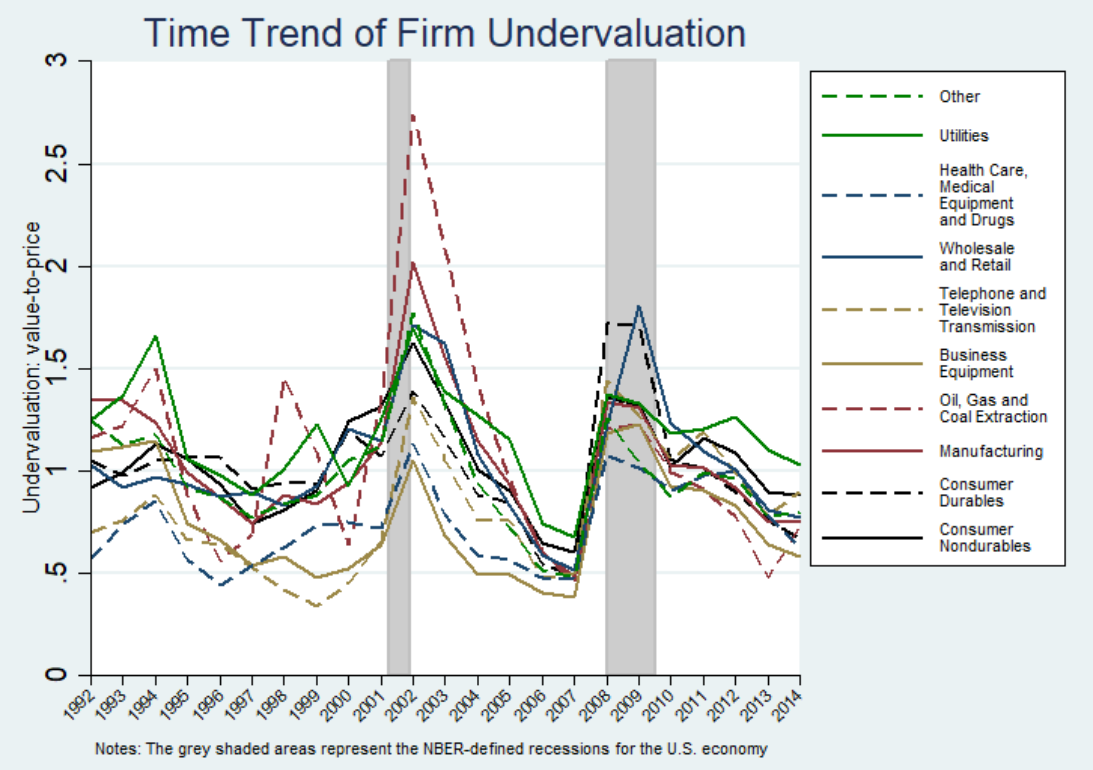




\section{Figure IV}

\section{Issuance of Trade Credit by Valuation Group}

This figure shows the year-by-year trade credit (i.e., accounts payable) by valuation group constructed according to the 10-90\% undervaluation cutoffs. In Panel A, trade credit is scaled by total assets and multiplied by 100. Panel B calculates the change in trade credit, scaled by total assets and multiplied by 100 . Firms in the bottom, medium, and upper quantile of the uninstrumented value-to-price ratio are classified in the High, Medium, and Low valuation groups, respectively. The sample is drawn from the CRSP and Compustat Merged database for non-financial U.S. firms over the period from 1992 through 2014.

\section{Panel A: Trade Credit Level}

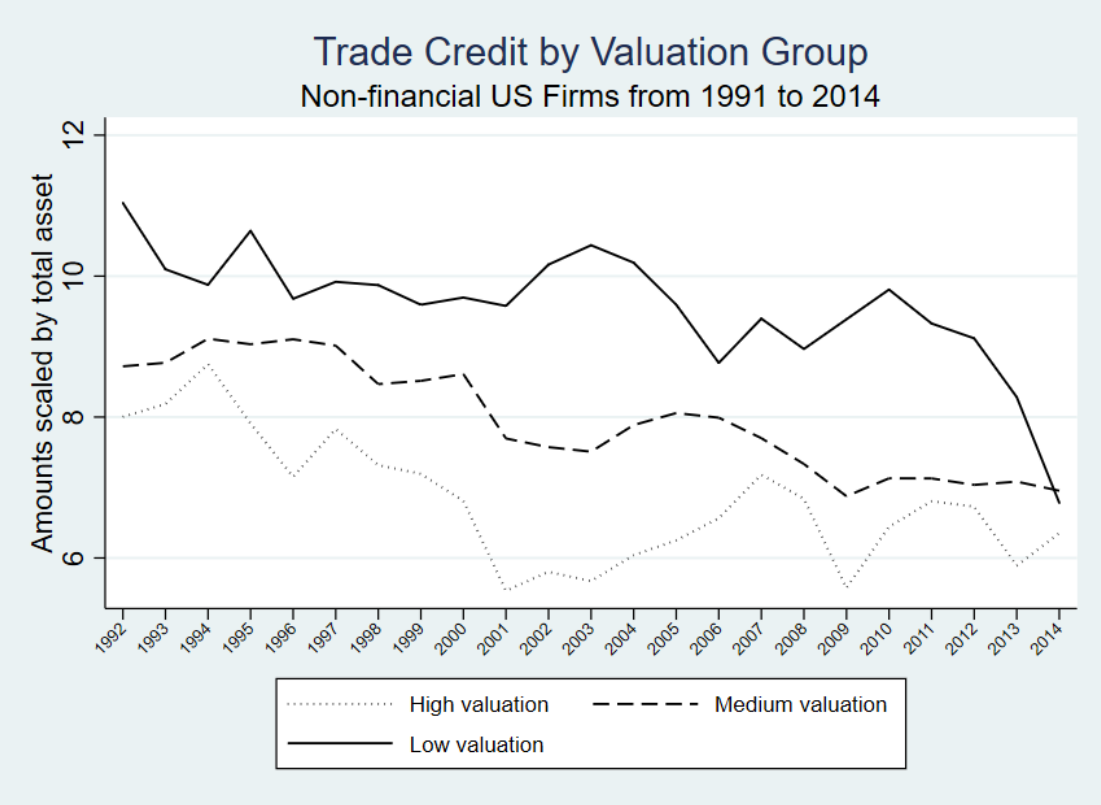

Panel B: Change in Trade Credit

Trade Credit by Valuation Group

Non-financial US Firms from 1991 to 2014

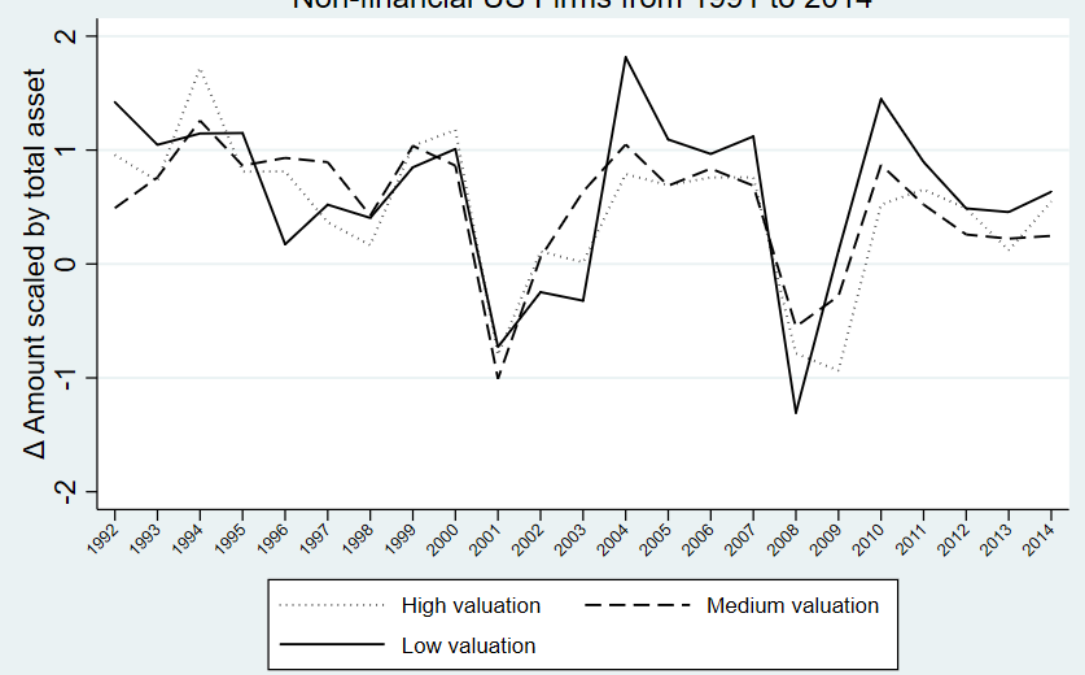


Table I

Summary Statistics

\begin{tabular}{|c|c|c|c|c|c|}
\hline & Mean & $\mathrm{P} 25$ & Median & P75 & Std Dev \\
\hline$T C$ & 8.16 & 3.37 & 6.18 & 10.44 & 7.45 \\
\hline$d T C$ & 0.53 & -0.54 & 0.34 & 1.56 & 3.67 \\
\hline$U N$ & 0.95 & 0.39 & 0.69 & 1.16 & 1.00 \\
\hline Outflow & 0.06 & 0.00 & 0.03 & 0.07 & 0.15 \\
\hline$d S$ & 1.99 & -0.92 & 0.47 & 2.90 & 10.45 \\
\hline$d S T D$ & 0.31 & -0.71 & 0.00 & 1.84 & 7.64 \\
\hline$d L T D$ & 2.52 & 0.00 & 0.00 & 3.29 & 8.53 \\
\hline$d M i s L$ & 1.45 & -0.68 & 1.15 & 3.44 & 6.34 \\
\hline$D D 1$ & 1.70 & 0.00 & 0.37 & 1.92 & 3.91 \\
\hline$d A$ & 6.50 & -1.85 & 6.05 & 15.47 & 21.62 \\
\hline$N e g Y$ & -2.96 & 0.00 & 0.00 & 0.00 & 11.57 \\
\hline Pos $Y$ & 5.50 & 0.47 & 4.25 & 8.22 & 5.81 \\
\hline$D$ & 1.13 & 0.00 & 0.00 & 1.55 & 2.36 \\
\hline$N o D$ & 0.57 & 0.00 & 1.00 & 1.00 & 0.50 \\
\hline Size & 6.03 & 4.43 & 5.88 & 7.52 & 2.17 \\
\hline NetLev & 0.04 & -0.16 & 0.08 & 0.27 & 0.31 \\
\hline PosSale & 0.16 & 0.00 & 0.07 & 0.20 & 0.29 \\
\hline NegSale & -0.04 & -0.01 & 0.00 & 0.00 & 0.12 \\
\hline NoSale & 0.00 & 0.00 & 0.00 & 0.00 & 0.04 \\
\hline Age & 2.73 & 2.08 & 2.71 & 3.30 & 0.75 \\
\hline $\mathrm{Age}^{2}$ & 8.00 & 4.32 & 7.33 & 10.86 & 4.22 \\
\hline CurrAsset & 0.38 & 0.21 & 0.37 & 0.53 & 0.21 \\
\hline Cash & 0.11 & 0.02 & 0.06 & 0.16 & 0.13 \\
\hline Profit & 0.03 & 0.01 & 0.04 & 0.08 & 0.14 \\
\hline Number of observations & 51,109 & & & & \\
\hline Number of firms & 5,377 & & & & \\
\hline
\end{tabular}




\section{Table II}

Univariate Test: Firm Undervaluation and Trade Credit

\begin{tabular}{lcccc}
\hline & & $(1)$ & $(2)$ & $(3)$ \\
& Observations & $U N$ & $T C$ & $d T C$ \\
\hline 1-Undervalued & 5,102 & 3.061 & 9.839 & 0.626 \\
2 & 40,883 & 0.788 & 8.096 & 0.522 \\
3-Overvalued & 5,124 & 0.141 & 6.976 & 0.481 \\
Difference 1 - 3 & & $2.920^{* * *}$ & $2.864^{* * *}$ & $0.145^{*}$ \\
(t-Stat) & & $(119.288)$ & $(18.045)$ & $(1.701)$ \\
Difference 1 - & & $2.273^{* * *}$ & $1.744^{* * *}$ & $0.105^{* *}$ \\
(t-Stat) & $(213.978)$ & $(15.802)$ & $(1.946)$ \\
\hline
\end{tabular}

This table compares the use of trade credit across different stock valuation levels. Portfolios are constructed based on the uninstrumented undervaluation measure. Time-series mean values of the uninstrumented undervaluation measure ( $U N$, the value-to-price ratio), the level of trade credit, and the change in trade credit are reported for three portfolios constructed according to the $110 \%-90 \%$ cutoffs of the uninstrumented undervaluation measure. The test of differences between the portfolios are presented at the bottom of the table, with the associated t-statistics reported in parentheses. ${ }^{* * *} . * *$. and ${ }^{*}$ show that the coefficient is significant at the $1 \%, 5 \%$, and $10 \%$ level, respectively. 


\section{Table III}

Firm Undervaluation and Trade Credit

Panel A: OLS

\begin{tabular}{|c|c|c|c|c|}
\hline Dependent Variable & (1) & (2) & (3) & (4) \\
\hline $\begin{array}{l}\text { Firm Undervaluation: } \\
U N\end{array}$ & $\begin{array}{l}0.09^{* * *} \\
(4.27)\end{array}$ & $\begin{array}{l}0.11^{* * *} \\
(5.01)\end{array}$ & $\begin{array}{l}0.14^{* * *} \\
(6.55)\end{array}$ & $\begin{array}{l}0.12^{* * * *} \\
(5.30)\end{array}$ \\
\hline $\begin{array}{l}\text { Firm Characteristics: } \\
\text { Size }\end{array}$ & & $\begin{array}{l}0.07^{* * * *} \\
(2.95)\end{array}$ & $\begin{array}{l}0.10^{* * *} \\
(2.65)\end{array}$ & $\begin{array}{l}0.11^{* * * *} \\
(3.00)\end{array}$ \\
\hline NetLev & & $\begin{array}{l}-0.53^{* * *} \\
(-5.14)\end{array}$ & $\begin{array}{l}-0.85^{* * *} \\
(-6.82)\end{array}$ & $\begin{array}{l}-0.77^{* * *} \\
(-6.18)\end{array}$ \\
\hline NoD & & $\begin{array}{l}-0.05 \\
(-1.07)\end{array}$ & $\begin{array}{l}-0.09^{*} \\
(-1.77)\end{array}$ & $\begin{array}{l}-0.07 \\
(-1.52)\end{array}$ \\
\hline PosSale & & & $\begin{array}{l}0.42^{* * * *} \\
(2.82)\end{array}$ & $\begin{array}{l}0.39^{* * *} \\
(2.57)\end{array}$ \\
\hline NegSale & & & $\begin{array}{l}2.60^{* * *} \\
(10.48)\end{array}$ & $\begin{array}{l}2.45^{* * *} \\
(9.63)\end{array}$ \\
\hline NoSale & & & $\begin{array}{l}-2.87 \\
(-1.58)\end{array}$ & $\begin{array}{l}-2.88 \\
(-1.59)\end{array}$ \\
\hline Age & & & $\begin{array}{l}0.46^{* *} \\
(2.37)\end{array}$ & $\begin{array}{c}0.41 \\
(1.10)\end{array}$ \\
\hline$A g e^{2}$ & & & $\begin{array}{l}-0.07^{*} \\
(-1.65)\end{array}$ & $\begin{array}{l}-0.06 \\
(-0.55)\end{array}$ \\
\hline CurrAsset & & & $\begin{array}{l}2.16^{* * *} \\
(8.77)\end{array}$ & $\begin{array}{l}2.12^{* * * *} \\
(8.68)\end{array}$ \\
\hline Cash & & & $\begin{array}{l}-1.68^{* * * *} \\
(-5.95)\end{array}$ & $\begin{array}{c}-1.65^{* * * *} \\
(-5.79)\end{array}$ \\
\hline Profit & & & $\begin{array}{l}-3.77^{* * * *} \\
(-5.82)\end{array}$ & $\begin{array}{l}-3.88^{* * * *} \\
(-5.86)\end{array}$ \\
\hline Firm FEs & Yes & Yes & Yes & Yes \\
\hline Year FEs & No & No & No & Yes \\
\hline $\begin{array}{l}\text { Observations } \\
\text { Adjusted } R^{2}\end{array}$ & $\begin{array}{c}51,109 \\
0.001\end{array}$ & $\begin{array}{c}51,109 \\
0.002\end{array}$ & $\begin{array}{c}51,109 \\
0.042\end{array}$ & $\begin{array}{c}51,109 \\
0.049\end{array}$ \\
\hline
\end{tabular}


Table III - Continued

Panel B: $2 S L S$

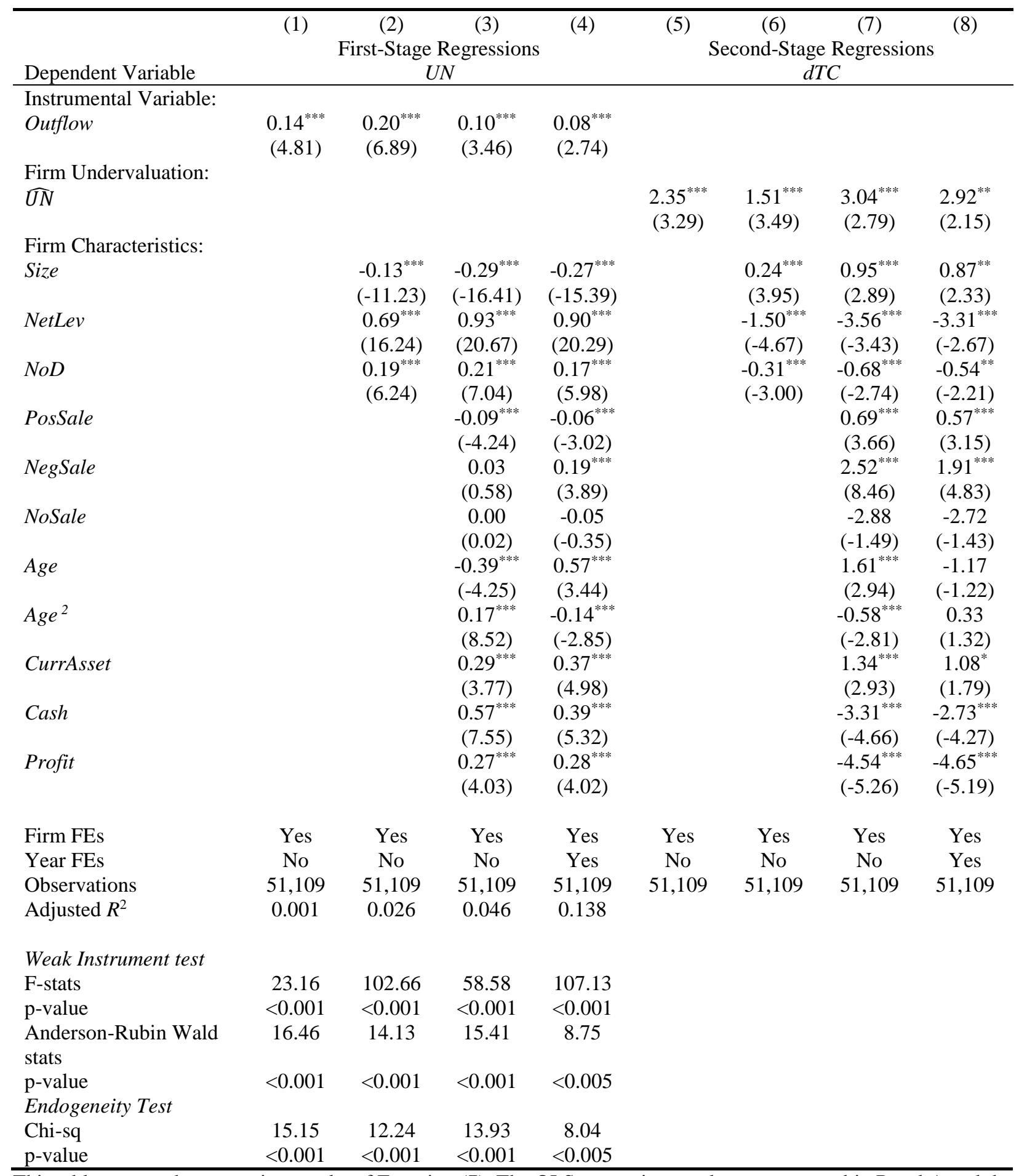

This table reports the regression results of Equation (7). The OLS regression results are presented in Panel A and the 2SLS regression results are presented in Panel B. Standard errors are clustered at the firm level, t-statistics are in parentheses, and ${ }^{* * * *}, * *$ and ${ }^{*}$ show that the coefficient is significant at the $1 \%, 5 \%$, and $10 \%$ level, respectively. 


\section{Table IV}

Firm Undervaluation and the Allocation between Trade Credit and Formal Sources of Finance

Panel A: OLS

\begin{tabular}{|c|c|c|c|c|}
\hline Dependent Variable & \multicolumn{4}{|c|}{$d T C$} \\
\hline Firm Undervaluation: & & & & \\
\hline$U N$ & $\begin{array}{l}0.16^{* * *} \\
(6.66)\end{array}$ & $\begin{array}{c}0.17^{* * * *} \\
(6.88)\end{array}$ & $\begin{array}{l}0.17^{* * *} \\
(6.83)\end{array}$ & $\begin{array}{l}0.14^{* * *} \\
(5.93)\end{array}$ \\
\hline $\begin{array}{l}\text { Cash Flow Constraint: } \\
d A\end{array}$ & $\begin{array}{l}0.11^{* * *} \\
(26.15)\end{array}$ & $\begin{array}{l}0.11^{* * *} \\
(24.86)\end{array}$ & $\begin{array}{l}0.09^{* * *} \\
(20.71)\end{array}$ & $\begin{array}{l}0.09^{* * *} \\
(20.52)\end{array}$ \\
\hline $\operatorname{Neg} Y$ & $\begin{array}{l}-0.09^{* * * *} \\
(-10.95)\end{array}$ & $\begin{array}{l}-0.09^{* * * *} \\
(-10.76)\end{array}$ & $\begin{array}{l}0.05 \\
(0.70)\end{array}$ & $\begin{array}{l}0.06 \\
(0.74)\end{array}$ \\
\hline $\operatorname{Pos} Y$ & $\begin{array}{c}-0.05^{* * *} \\
(-6.75)\end{array}$ & $\begin{array}{l}-0.05^{* * * *} \\
(-6.97)\end{array}$ & $\begin{array}{c}0.06 \\
(0.77)\end{array}$ & $\begin{array}{c}0.06 \\
(0.80)\end{array}$ \\
\hline$D$ & $\begin{array}{l}0.08^{* * * *} \\
(8.63)\end{array}$ & $\begin{array}{l}0.07^{* * * *} \\
(7.00)\end{array}$ & $\begin{array}{l}0.07^{* * *} \\
(7.45)\end{array}$ & $\begin{array}{l}0.07^{* * * *} \\
(7.56)\end{array}$ \\
\hline$d M i s L$ & $\begin{array}{l}-0.08^{* * *} \\
(-12.37)\end{array}$ & $\begin{array}{l}-0.08^{* * * *} \\
(-12.13)\end{array}$ & $\begin{array}{l}-0.09^{* * * *} \\
(-13.09)\end{array}$ & $\begin{array}{l}-0.09^{* * * *} \\
(-13.10)\end{array}$ \\
\hline$D D 1$ & $\begin{array}{l}0.03^{* * *} \\
(4.36)\end{array}$ & $\begin{array}{l}0.04^{* * *} \\
(4.76)\end{array}$ & $\begin{array}{l}0.03^{* * *} \\
(4.56)\end{array}$ & $\begin{array}{l}0.03^{* * * *} \\
(4.42)\end{array}$ \\
\hline $\begin{array}{l}\text { Firm Characteristics: } \\
\text { Size }\end{array}$ & & $\begin{array}{c}0.01 \\
(0.32)\end{array}$ & $\begin{array}{c}0.12^{* * * *} \\
(2.95)\end{array}$ & $0.13^{* * *}$ \\
\hline NetLev & & $\begin{array}{l}-0.32^{* *} \\
(-2.44)\end{array}$ & $\begin{array}{c}-0.54^{* * *} \\
(-3.59)\end{array}$ & $\begin{array}{c}-0.47^{* * * *} \\
(-3.10)\end{array}$ \\
\hline NoD & & $\begin{array}{l}-0.10 \\
(-1.63)\end{array}$ & $\begin{array}{l}-0.06 \\
(-1.02)\end{array}$ & $\begin{array}{c}-0.04 \\
(-0.75)\end{array}$ \\
\hline PosSale & & & $\begin{array}{l}1.73^{* * * *} \\
(10.58)\end{array}$ & $\begin{array}{l}1.73^{* * *} \\
(10.51)\end{array}$ \\
\hline NegSale & & & $\begin{array}{l}4.29^{* * * *} \\
(14.04)\end{array}$ & $\begin{array}{l}4.22^{* * *} \\
(13.52)\end{array}$ \\
\hline NoSale & & & $\begin{array}{l}-6.25^{* *} \\
(-1.99)\end{array}$ & $\begin{array}{l}-6.26^{* * *} \\
(-2.00)\end{array}$ \\
\hline Age & & & $\begin{array}{l}0.73^{* * *} \\
(3.42)\end{array}$ & $\begin{array}{l}0.85^{* *} \\
(2.06)\end{array}$ \\
\hline $\mathrm{Age}^{2}$ & & & $\begin{array}{l}-0.11^{* * * *} \\
(-2.62)\end{array}$ & $\begin{array}{l}-0.16 \\
(-1.41)\end{array}$ \\
\hline CurrAsset & & & $\begin{array}{l}2.82^{* * *} \\
(9.62)\end{array}$ & $\begin{array}{l}2.75^{* * * *} \\
(9.44)\end{array}$ \\
\hline Cash & & & $\begin{array}{c}-0.88^{* * * *} \\
(-3.01)\end{array}$ & $\begin{array}{r}-0.87^{* * * *} \\
(-2.94)\end{array}$ \\
\hline Profit & & & $\begin{array}{l}-13.55^{*} \\
(-1.75)\end{array}$ & $\begin{array}{l}-13.77^{*} \\
(-1.80)\end{array}$ \\
\hline Firm FEs & Yes & Yes & Yes & Yes \\
\hline Year FEs & No & No & No & Yes \\
\hline Observations & 51,109 & 51,109 & 51,109 & 51,109 \\
\hline Adjusted $R^{2}$ & 0.196 & 0.196 & 0.244 & 0.249 \\
\hline
\end{tabular}


Table IV - Continued

Panel B: 2SLS

\begin{tabular}{|c|c|c|c|c|c|c|c|c|}
\hline \multirow{2}{*}{$\begin{array}{l}\text { Dependent Variable } \\
\text { Instrumental Variable: } \\
\text { Outflow }\end{array}$} & \multicolumn{4}{|c|}{$\begin{array}{c}\text { First-Stage Regressions } \\
U N\end{array}$} & \multicolumn{4}{|c|}{\begin{tabular}{l} 
(5) \\
Second-Stage Regressions \\
\multicolumn{2}{c}{$d T C$}
\end{tabular}} \\
\hline & $\begin{array}{l}0.14^{* * * *} \\
(4.80)\end{array}$ & $\begin{array}{c}0.20^{* * * *} \\
(6.98)\end{array}$ & $\begin{array}{c}0.09^{* * *} \\
(3.41)\end{array}$ & $\begin{array}{l}0.08^{* * *} \\
(2.67)\end{array}$ & & & & \\
\hline $\begin{array}{l}\text { Firm Undervaluation: } \\
\widehat{U N}\end{array}$ & & & & & $\begin{array}{l}2.07^{* * *} \\
(2.91)\end{array}$ & $\begin{array}{l}1.43^{* * * *} \\
(3.23)\end{array}$ & $\begin{array}{l}2.71^{* *} \\
(2.50)\end{array}$ & $\begin{array}{c}2.76^{*} \\
(1.96)\end{array}$ \\
\hline $\begin{array}{l}\text { Cash Flow Constraint: } \\
d A\end{array}$ & $\begin{array}{l}-0.00^{* * *} \\
(-11.79)\end{array}$ & $\begin{array}{l}-0.01^{* * *} \\
(-14.17)\end{array}$ & $\begin{array}{l}-0.01^{* * *} \\
(-15.42)\end{array}$ & $\begin{array}{l}-0.01^{* * *} \\
(-15.88)\end{array}$ & $\begin{array}{l}0.12^{* * * *} \\
(22.20)\end{array}$ & $\begin{array}{l}0.12^{* * *} \\
(23.16)\end{array}$ & $\begin{array}{l}0.11^{* * *} \\
(13.28)\end{array}$ & $\begin{array}{l}0.11^{* * * *} \\
(11.09)\end{array}$ \\
\hline$N e g Y$ & $\begin{array}{l}0.01^{* * *} \\
(7.74)\end{array}$ & $\begin{array}{l}0.01^{* * *} \\
(8.25)\end{array}$ & $\begin{array}{l}-0.04 \\
(-1.64)\end{array}$ & $\begin{array}{l}-0.04^{*} \\
(-1.85)\end{array}$ & $\begin{array}{l}-0.11^{\text {**** }} \\
(-11.33)\end{array}$ & $\begin{array}{l}-0.10^{* * *} \\
(-11.86)\end{array}$ & $\begin{array}{l}0.15 \\
(1.46)\end{array}$ & $\begin{array}{c}0.17 \\
(1.46)\end{array}$ \\
\hline PosY & $\begin{array}{l}0.01^{* * * *} \\
(3.71)\end{array}$ & $\begin{array}{l}0.00^{* * * *} \\
(3.42)\end{array}$ & $\begin{array}{l}-0.05^{*} \\
(-1.94)\end{array}$ & $\begin{array}{l}-0.05^{* *} \\
(-1.98)\end{array}$ & $\begin{array}{c}-0.06^{* * *} \\
(-6.88)\end{array}$ & $\begin{array}{l}-0.06^{* * *} \\
(-7.37)\end{array}$ & $\begin{array}{l}0.18 \\
(1.63)\end{array}$ & $\begin{array}{c}0.18 \\
(1.54)\end{array}$ \\
\hline$D$ & $\begin{array}{c}-0.02^{* * * *} \\
(-6.13)\end{array}$ & $\begin{array}{l}-0.00 \\
(-0.63)\end{array}$ & $\begin{array}{l}-0.01^{* *} \\
(-2.17)\end{array}$ & $\begin{array}{l}-0.00 \\
(-1.37)\end{array}$ & $\begin{array}{l}0.12^{* * *} \\
(6.33)\end{array}$ & $\begin{array}{l}0.08^{* * * *} \\
(6.60)\end{array}$ & $\begin{array}{l}0.09^{* * * *} \\
(5.84)\end{array}$ & $\begin{array}{l}0.09^{* * * *} \\
(5.86)\end{array}$ \\
\hline dMisL & $\begin{array}{l}0.01^{* * *} \\
(9.35)\end{array}$ & $\begin{array}{l}0.01^{* * *} \\
(9.28)\end{array}$ & $\begin{array}{l}0.01^{\text {**** }} \\
(9.29)\end{array}$ & $\begin{array}{l}0.01^{* * * *} \\
(9.28)\end{array}$ & $\begin{array}{l}-0.10^{* * * *} \\
(-10.73)\end{array}$ & $\begin{array}{l}-0.09^{* * *} \\
(-11.92)\end{array}$ & $\begin{array}{l}-0.11^{* * *} \\
(-9.37)\end{array}$ & $\begin{array}{l}-0.11^{* * *} \\
(-8.12)\end{array}$ \\
\hline$D D 1$ & $\begin{array}{l}0.02^{* * * *} \\
(8.05)\end{array}$ & $\begin{array}{l}0.01^{* * *} \\
(5.10)\end{array}$ & $\begin{array}{l}0.01^{* * * *} \\
(4.65)\end{array}$ & $\begin{array}{l}0.01^{* * * *} \\
(3.94)\end{array}$ & $\begin{array}{c}0.00 \\
(0.35)\end{array}$ & $\begin{array}{l}0.03^{* * *} \\
(2.79)\end{array}$ & $\begin{array}{c}0.01 \\
(1.07)\end{array}$ & $\begin{array}{c}0.02 \\
(1.20)\end{array}$ \\
\hline Firm $C$ & & & & & & & & \\
\hline Size & & $\begin{array}{l}-0.15^{* * *} \\
(-12.67)\end{array}$ & $\begin{array}{l}-0.33^{* * *} \\
(-17.79)\end{array}$ & $\begin{array}{l}-0.30^{* * *} \\
(-16.83)\end{array}$ & & $\begin{array}{c}0.19^{* * * *} \\
(2.63)\end{array}$ & $\begin{array}{c}0.96^{* * *} \\
(2.63)\end{array}$ & $\begin{array}{l}0.92^{* *} \\
(2.12)\end{array}$ \\
\hline NetLev & & $\begin{array}{l}0.60^{* * * *} \\
(14.02)\end{array}$ & $\begin{array}{l}0.81^{* * * *} \\
(18.00)\end{array}$ & $\begin{array}{l}0.79^{* * * *} \\
(17.79)\end{array}$ & & $\begin{array}{c}-1.07^{* * * *} \\
(-3.57)\end{array}$ & $\begin{array}{c}-2.60^{* * * *} \\
(-2.88)\end{array}$ & $\begin{array}{l}-2.53^{* *} \\
(-2.24)\end{array}$ \\
\hline$N o D$ & & $\begin{array}{l}0.19^{* * * *} \\
(5.91)\end{array}$ & $\begin{array}{c}0.18^{* * *} \\
(5.84)\end{array}$ & $\begin{array}{c}0.15^{* * *} \\
(5.22)\end{array}$ & & $\begin{array}{c}-0.33^{* * *} \\
(-2.96)\end{array}$ & $\begin{array}{l}-0.52^{* *} \\
(-2.32)\end{array}$ & $\begin{array}{l}-0.45^{*} \\
(-1.86)\end{array}$ \\
\hline PosSale & & & $\begin{array}{c}0.02 \\
(1.03)\end{array}$ & $\begin{array}{l}0.04^{* *} \\
(1.96)\end{array}$ & & & $\begin{array}{l}1.67^{* * * *} \\
(9.53)\end{array}$ & $\begin{array}{l}1.61^{* * * *} \\
(8.77)\end{array}$ \\
\hline NegSale & & & $\begin{array}{l}0.11^{\text {*** }} \\
(2.13)\end{array}$ & $\begin{array}{l}0.27^{* * * *} \\
(5.46)\end{array}$ & & & $\begin{array}{l}4.01^{* * * *} \\
(11.77)\end{array}$ & $\begin{array}{l}3.51^{* * * *} \\
(7.09)\end{array}$ \\
\hline NoSale & & & $\begin{array}{c}0.03 \\
(0.16)\end{array}$ & $\begin{array}{c}-0.04 \\
(-0.23)\end{array}$ & & & $\begin{array}{l}-6.31^{*} \\
(-1.94)\end{array}$ & $\begin{array}{l}-6.16^{*} \\
(-1.91)\end{array}$ \\
\hline Age & & & $\begin{array}{c}-0.45^{* * * *} \\
(-4.88)\end{array}$ & $\begin{array}{c}0.53^{* * *} \\
(3.20)\end{array}$ & & & $\begin{array}{l}1.88^{* * * *} \\
(3.21)\end{array}$ & $\begin{array}{l}-0.51 \\
(-0.55)\end{array}$ \\
\hline$A g e^{2}$ & & & $\begin{array}{c}0.19^{* * * *} \\
(9.32)\end{array}$ & $\begin{array}{c}-0.13^{* * *} \\
(-2.63)\end{array}$ & & & $\begin{array}{c}-0.60^{* * * *} \\
(-2.74)\end{array}$ & $\begin{array}{c}0.17 \\
(0.69)\end{array}$ \\
\hline CurrAsset & & & $\begin{array}{l}0.17^{* *} \\
(2.13)\end{array}$ & $\begin{array}{l}0.22^{* * * *} \\
(2.94)\end{array}$ & & & $\begin{array}{c}2.40^{* * * *} \\
(6.02)\end{array}$ & $\begin{array}{l}2.17^{* * * *} \\
(4.60)\end{array}$ \\
\hline Cash & & & $\begin{array}{c}0.51^{* * * *} \\
(6.71)\end{array}$ & $\begin{array}{l}0.30^{* * * *} \\
(4.10)\end{array}$ & & & $\begin{array}{c}-2.18^{* * * *} \\
(-3.31)\end{array}$ & $\begin{array}{c}-1.66^{* * * *} \\
(-2.98)\end{array}$ \\
\hline Profit & & & $\begin{array}{l}4.88^{* *} \\
(2.04)\end{array}$ & $\begin{array}{l}5.12^{* *} \\
(2.23)\end{array}$ & & & $\begin{array}{c}-25.96^{* *} \\
(-2.35)\end{array}$ & $\begin{array}{c}-27.13^{* * *} \\
(-2.23)\end{array}$ \\
\hline Firm FEs & Yes & Yes & Yes & Yes & Yes & Yes & Yes & Yes \\
\hline Year FEs & No & No & No & Yes & No & No & No & Yes \\
\hline Observations & 51,109 & 51,109 & 51,109 & 51,109 & 51,109 & 51,109 & 51,109 & 51,109 \\
\hline Adjusted $R^{2}$ & 0.013 & 0.036 & 0.055 & 0.147 & & & & \\
\hline
\end{tabular}


Weak Instrument test

F-stats

p-value

43.65

$<0.001$

59.85

$<0.001$

48.48

94.10

Anderson-Rubin Wald

11.61

11.91

$<0.001$

$<0.001$

stats

p-value

$<0.001$

$<0.001$

$<0.001$

$<0.01$

Endogeneity Test

Chi-sq

9.70

9.13

9.69

6.13

p-value

$<0.005$

$<0.005$

$<0.005$

0.01

This table reports the regression results of Equation (8a). The OLS regression results are presented in Panel A and the 2SLS regression results are presented in Panel B. Standard errors are clustered at the firm level, t-statistics are in parentheses, and ${ }^{* * *},{ }^{* *}$, and ${ }^{*}$ show that the coefficient is significant at the $1 \%, 5 \%$, and $10 \%$ level, respectively. 


\section{Table V}

\section{Firm Undervaluation and the Allocation between Trade Credit and Short-Term Financial Debt}

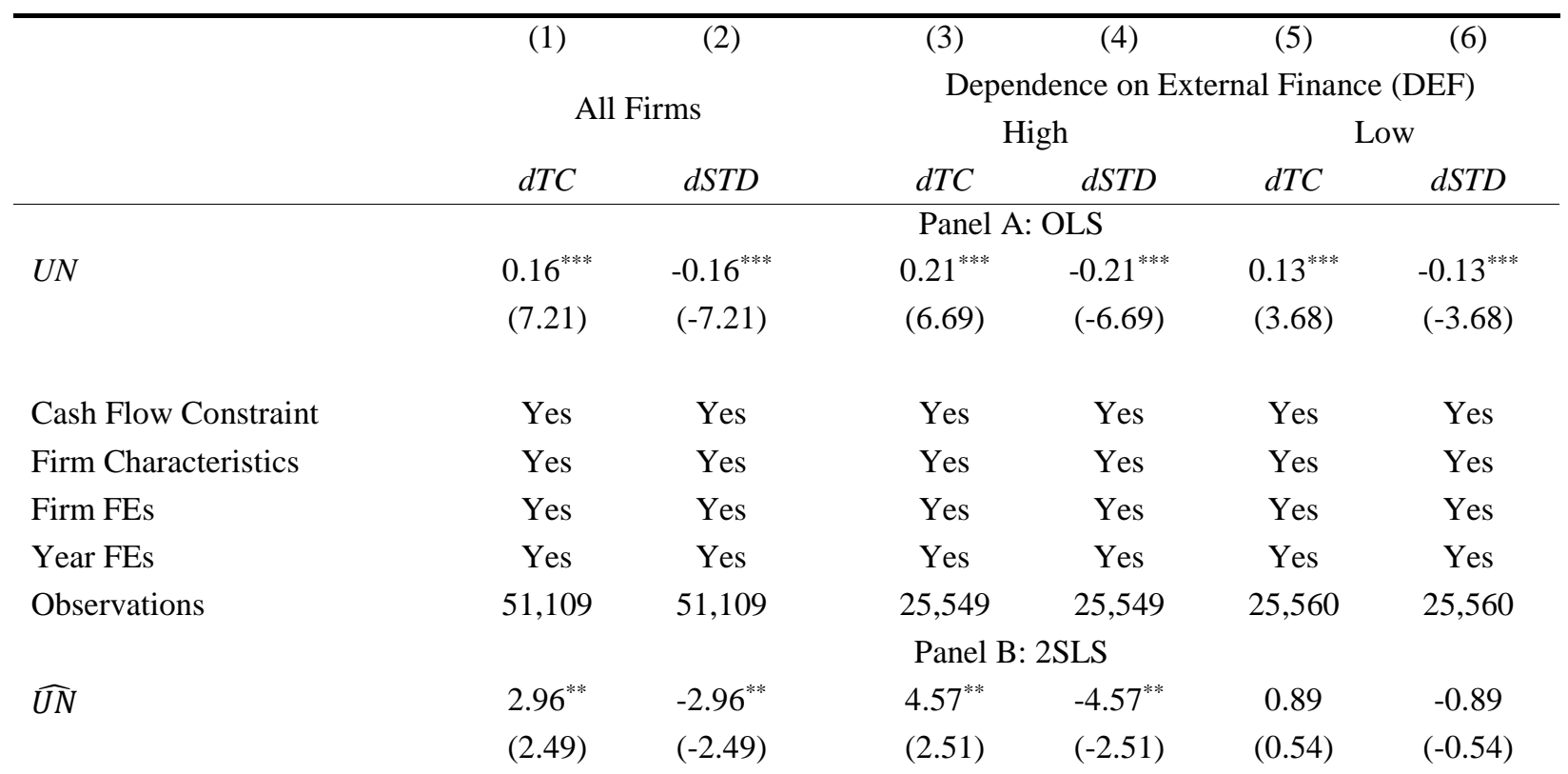

First-Stage Regression

Instrument Variable:

Outflow

$0.07^{* *}$

(2.42)

$\begin{array}{lcccccc}\text { Cash Flow Constraint } & \text { Yes } & \text { Yes } & \text { Yes } & \text { Yes } & \text { Yes } & \text { Yes } \\ \text { Firm Characteristics } & \text { Yes } & \text { Yes } & \text { Yes } & \text { Yes } & \text { Yes } & \text { Yes } \\ \text { Firm FEs } & \text { Yes } & \text { Yes } & \text { Yes } & \text { Yes } & \text { Yes } & \text { Yes } \\ \text { Year FEs } & \text { Yes } & \text { Yes } & \text { Yes } & \text { Yes } & \text { Yes } & \text { Yes } \\ \text { Observations } & 51,109 & 51,109 & 25,549 & 25,549 & 25,560 & 25,560\end{array}$

This table presents the OLS and 2SLS regression resultss for the split between trade credit and short-term financing debt (dSTD). Cash flow constraints are imposed in the spirit of Fama and French (2012). Regression results are presented for the full sample in column (1) and column (2). In columns (3) - (6), regression results are separately presented for sub-samples of firms with high and low dependence on external finance, based on 2-quantiles. For brevity, regression coefficients are reported only for the undervaluation measure, which is the one-year lagged valueto-price ratio in the OLS regressions and the one-year lagged instrumented value-to-price ratio in the 2SLS regressions; standard errors are clustered at the firm level, t-statistics are in parentheses, and ${ }^{* * *},{ }^{* *}$, and ${ }^{*}$ show that the coefficient is significant at the $1 \%, 5 \%$, and $10 \%$ level, respectively. 


\section{Table VI}

Firm Undervaluation and Trade Credit: Heterogeneity

\begin{tabular}{|c|c|c|c|c|c|c|c|}
\hline & & & & (1) & (2) & (3) & (4) \\
\hline & & & & OLS & 2SLS & OLS & 2SLS \\
\hline & & & & & Variable & f Interes & \\
\hline & & & Observations & $U N$ & $\widehat{U N}$ & $U N$ & $\widehat{U N}$ \\
\hline & Small & Coef & 25,560 & $0.09^{* * *}$ & $2.27^{*}$ & $0.16^{* * * *}$ & 1.41 \\
\hline Firm Size (Size) & & t-Stat & & $(2.76)$ & $(1.79)$ & $(5.39)$ & $(1.00)$ \\
\hline & Big & Coef & 25,549 & $0.18^{* * *}$ & $3.67^{* *}$ & $0.22^{* * * *}$ & $3.27^{*}$ \\
\hline & & t-Stat & & $(6.30)$ & $(2.22)$ & $(5.06)$ & $(1.74)$ \\
\hline & Low & Coef & 25,560 & $0.10^{* * * *}$ & 1.13 & $0.14^{* * * *}$ & 1.12 \\
\hline Dependence on External Finance (DEF) & & t-Stat & & $(2.95)$ & $(0.81)$ & $(3.83)$ & $(0.71)$ \\
\hline & High & Coef & 25,549 & $0.14^{* * *}$ & $3.80^{* *}$ & $0.22^{* * * *}$ & $3.76^{* *}$ \\
\hline & & t-Stat & & $(4.61)$ & $(2.50)$ & $(6.48)$ & $(2.19)$ \\
\hline & Low & Coef & 18,767 & $0.28^{* * * *}$ & $3.08^{* * *}$ & $0.27^{* * * *}$ & $3.93^{* *}$ \\
\hline Analyst Forecast Error (AFE) & & t-Stat & & $(6.75)$ & $(2.14)$ & $(6.05)$ & $(2.29)$ \\
\hline & High & Coef & 18,756 & $0.20^{* * * *}$ & $3.87^{* *}$ & $0.21^{* * * *}$ & $4.81^{* *}$ \\
\hline & & $\mathrm{t}-$ Stat & & $(6.00)$ & $(1.98)$ & $(6.20)$ & $(2.20)$ \\
\hline & Low & Coef & 18,767 & $0.18^{* * *}$ & $3.01^{* *}$ & $0.16^{* * * *}$ & $4.10^{* * *}$ \\
\hline Analyst Forecast Dispersion (AFD) & & t-Stat & & $(4.19)$ & $(2.23)$ & $(3.39)$ & $(2.79)$ \\
\hline & High & Coef & 18,756 & $0.23^{* * *}$ & $7.63^{* * *}$ & $0.27^{* * * *}$ & $8.77^{* * *}$ \\
\hline & & t-Stat & & $(7.36)$ & $(3.63)$ & $(7.90)$ & $(3.74)$ \\
\hline Cash-Flow Constraint & & & & No & No & Yes & Yes \\
\hline Firm Characteristics & & & & Yes & Yes & Yes & Yes \\
\hline Firm FEs & & & & Yes & Yes & Yes & Yes \\
\hline Year FEs & & & & Yes & Yes & Yes & Yes \\
\hline
\end{tabular}

This table performs sub-sample analyses based on firm size (Size), dependence on external finance (DEF), analyst forecast error (AFE), and analyst forecast dispersion (AFD). Regression results are separately presented for subsamples of firms classified based on 2-quantiles of Size, DEF, AFE, and AFD. For brevity, regression coefficients are reported only for the undervaluation measure, which is the one-year lagged value-to-price ratio in the OLS regressions and the one-year lagged instrumented value-to-price ratio in the 2SLS regressions; standard errors are clustered at the firm level; t-statistics are in parentheses; and ${ }^{* * *},{ }^{* *}$, and ${ }^{*}$ show that the coefficient is significant at the $1 \%, 5 \%$, and $10 \%$ level, respectively. 


\section{Table VII}

Firm Undervaluation, Trade Credit, and Firm-Supplier Relationships: Customer's Use of Trade Credit

\begin{tabular}{|c|c|c|c|c|c|c|c|c|c|c|c|}
\hline & \multicolumn{11}{|c|}{ Customer's Accounts Payable } \\
\hline & & & \multicolumn{3}{|c|}{ Size of Customers } & \multicolumn{3}{|c|}{ Supplier Pool } & \multicolumn{3}{|c|}{ Length of Relationship } \\
\hline & \multicolumn{2}{|c|}{ All } & Small & Medium & Large & Small & Medium & Large & Short & Medium & Long \\
\hline & (1) & $(2)$ & (3) & (4) & $(5)$ & (6) & (7) & $(8)$ & (9) & $(10)$ & $(11)$ \\
\hline \multicolumn{12}{|c|}{ Customer's Undervaluation: } \\
\hline \multirow[t]{2}{*}{$\widehat{C U N}$} & $15.02^{* * *}$ & $11.34^{* * *}$ & $23.62^{* *}$ & -1.52 & $10.33^{* * *}$ & -0.59 & $12.45^{* * *}$ & $34.10^{* * *}$ & 3.22 & -0.05 & $14.22^{* *}$ \\
\hline & $(3.74)$ & $(2.91)$ & $(2.49)$ & $(-0.39)$ & $(4.44)$ & $(-0.09)$ & $(3.55)$ & $(4.94)$ & $(0.40)$ & $(-0.01)$ & $(2.49)$ \\
\hline \multicolumn{12}{|c|}{ Customer's Characteristics: } \\
\hline \multirow[t]{2}{*}{ Size } & $0.99^{* * *}$ & $2.33^{* * *}$ & $4.70^{* * *}$ & $0.96^{* *}$ & $1.69^{* * *}$ & 0.99 & $3.35^{* * *}$ & $6.14^{* * *}$ & $5.32^{* * *}$ & $3.05^{* * *}$ & $2.09^{* * *}$ \\
\hline & $(2.62)$ & $(6.26)$ & $(5.11)$ & $(2.56)$ & $(7.58)$ & $(1.62)$ & $(6.88)$ & $(7.98)$ & $(5.44)$ & $(3.34)$ & $(4.20)$ \\
\hline \multirow[t]{2}{*}{ Age } & $2.74^{* * *}$ & 0.50 & 1.58 & $-1.77^{*}$ & $1.26^{* *}$ & -1.79 & -0.92 & $10.27^{* * *}$ & $-9.16^{* * * *}$ & -1.32 & $4.47^{* * *}$ \\
\hline & $(3.53)$ & $(0.62)$ & $(0.92)$ & $(-1.90)$ & $(2.23)$ & $(-1.57)$ & $(-1.09)$ & $(5.36)$ & $(-4.72)$ & $(-0.72)$ & $(2.84)$ \\
\hline \multirow[t]{2}{*}{ CurrAsset } & $1.91^{* * *}$ & $4.80^{* * *}$ & $6.45^{* * *}$ & $5.68^{* * *}$ & $3.82^{* * *}$ & $4.86^{* * *}$ & $3.80^{* * *}$ & $6.60^{* * *}$ & $14.24^{* * *}$ & $8.40^{* * *}$ & $4.01^{* * *}$ \\
\hline & $(2.02)$ & $(6.68)$ & $(3.51)$ & $(6.91)$ & $(7.32)$ & $(3.30)$ & $(5.07)$ & $(4.17)$ & $(7.20)$ & $(4.34)$ & $(3.87)$ \\
\hline \multirow[t]{2}{*}{ GrowthSale } & $1.43^{* *}$ & $2.04^{* * *}$ & $2.91^{*}$ & 1.22 & $2.26^{* * *}$ & 0.06 & $4.22^{* * *}$ & $2.88^{* *}$ & -1.29 & -1.19 & $4.11^{* * *}$ \\
\hline & $(2.12)$ & $(2.77)$ & $(1.73)$ & (1.64) & $(4.52)$ & $(0.05)$ & $(5.11)$ & (1.98) & $(-0.90)$ & $(-0.73)$ & $(3.17)$ \\
\hline \multirow[t]{2}{*}{ Lev } & $-11.42^{* * *}$ & $-8.22^{* * *}$ & $-12.81^{* * *}$ & $-5.94^{* * *}$ & $-3.27^{* * *}$ & -2.47 & $-11.29^{* * *}$ & $-13.92^{* * *}$ & $-6.81^{* *}$ & $-5.21^{* *}$ & $-9.03^{* * *}$ \\
\hline & $(-8.91)$ & $(-6.63)$ & $(-4.29)$ & $(-4.58)$ & $(-3.98)$ & $(-1.22)$ & $(-8.20)$ & $(-7.89)$ & $(-2.47)$ & $(-1.96)$ & $(-5.15)$ \\
\hline \multirow[t]{2}{*}{ Cash } & $-15.79^{* * *}$ & $-9.67^{* * *}$ & $-20.41^{* *}$ & 2.16 & $-6.96^{* * *}$ & 2.48 & $-13.55^{* * *}$ & $-32.15^{* * *}$ & 0.24 & 2.09 & $-11.81^{* *}$ \\
\hline & $(-3.88)$ & $(-2.59)$ & $(-2.27)$ & $(0.57)$ & $(-2.71)$ & $(0.40)$ & $(-3.92)$ & $(-4.58)$ & $(0.03)$ & $(0.25)$ & $(-2.13)$ \\
\hline
\end{tabular}




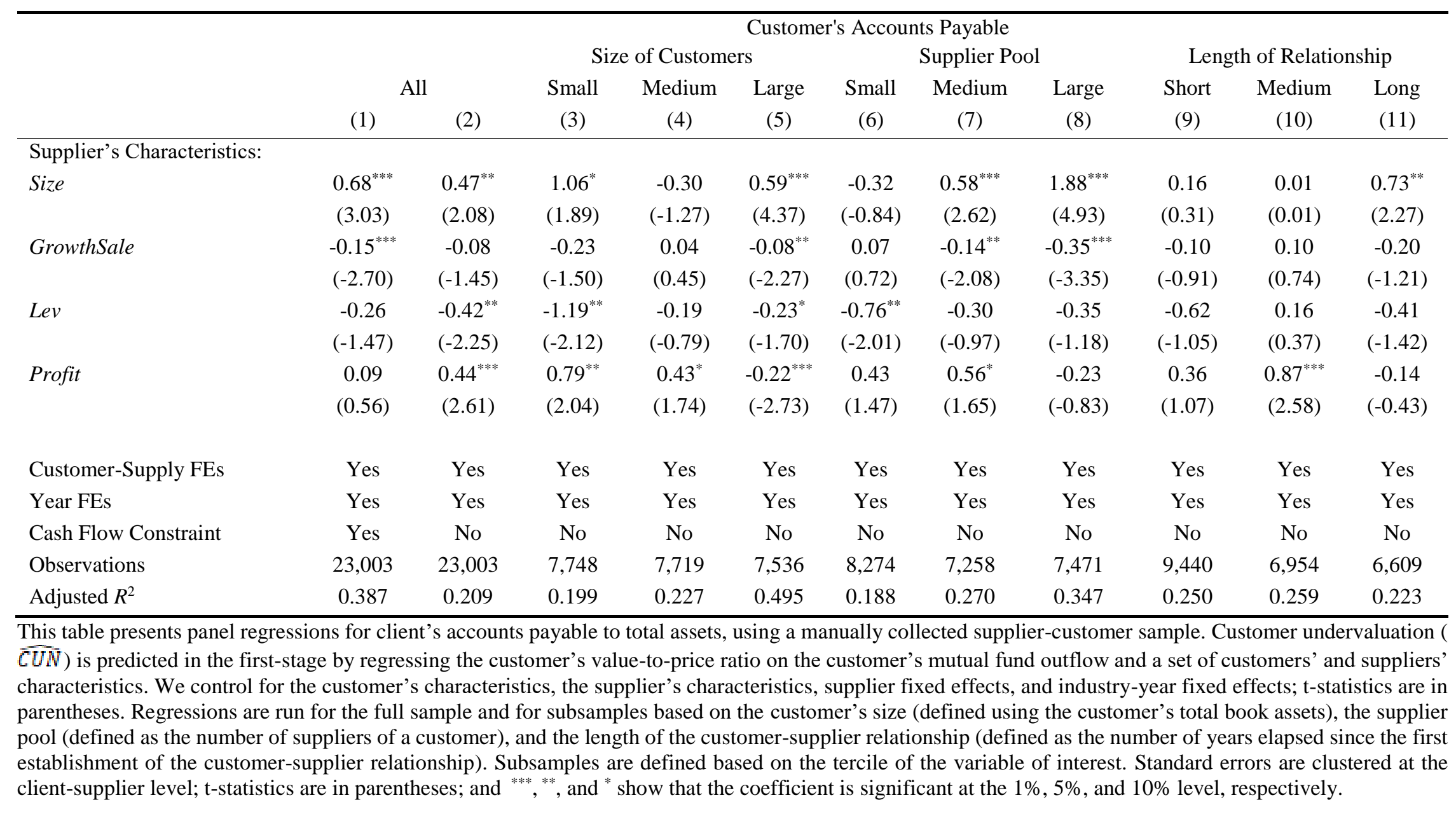




\section{Table VIII}

Firm Undervaluation, Trade Credit and Firm-Supplier Relationships: Supplier's Extension of Trade Credit

\begin{tabular}{|c|c|c|c|c|c|c|c|c|c|c|}
\hline & \multirow[b]{2}{*}{ (1) } & \multicolumn{3}{|c|}{ Size of Supplier } & \multicolumn{3}{|c|}{ Customer Pool } & \multicolumn{3}{|c|}{ Length of Relationship } \\
\hline & & (2) & (3) & (4) & (5) & (6) & (7) & (8) & (9) & $(10)$ \\
\hline & All & Small & Medium & Large & Small & Medium & Large & Short & Medium & Long \\
\hline & & & & & $\begin{array}{l}\text { Panel A } \\
\text { lier's Ac }\end{array}$ & $\begin{array}{l}\text { rade Cred } \\
\text { unts Rece }\end{array}$ & ble & & & \\
\hline \multirow[t]{2}{*}{ Customer's Undervaluation: $\widehat{C U N}$} & $12.33^{*}$ & $35.61^{*}$ & 7.30 & 1.65 & 16.27 & 6.37 & 3.05 & -4.16 & 29.21 & $17.41^{*}$ \\
\hline & $(1.73)$ & $(1.73)$ & $(0.79)$ & $(0.20)$ & $(1.43)$ & $(0.55)$ & $(0.20)$ & $(-0.34)$ & $(1.59)$ & $(1.73)$ \\
\hline Observations & 22,574 & 7,547 & 7,528 & 7,499 & 11,260 & 5,913 & 5,401 & 9,271 & 6,767 & 6,536 \\
\hline \multirow[t]{2}{*}{ Adjusted $R^{2}$} & 0.188 & 0.161 & 0.182 & 0.247 & 0.207 & 0.193 & 0.208 & 0.249 & 0.139 & 0.178 \\
\hline & \multicolumn{10}{|c|}{$\begin{array}{l}\text { Panel B: Net Trade Credit } \\
\text { Supplier's Accounts Receivable minus Accounts Payable }\end{array}$} \\
\hline \multirow[t]{2}{*}{ Customer's Undervaluation: $\widehat{C U N}$} & $16.86^{*}$ & 59.49 & 3.56 & $6.25^{*}$ & $32.61^{*}$ & 14.41 & 4.58 & 8.67 & 37.69 & 9.65 \\
\hline & $(1.83)$ & $(1.61)$ & $(0.73)$ & $(1.71)$ & $(1.74)$ & $(0.89)$ & $(0.74)$ & $(0.33)$ & $(1.12)$ & $(0.96)$ \\
\hline Observations & 22,574 & 7,547 & 7,528 & 7,499 & 11,260 & 5,913 & 5,401 & 9,271 & 6,767 & 6,536 \\
\hline Adjusted $R^{2}$ & 0.289 & 0.192 & 0.753 & 0.875 & 0.375 & -0.136 & 0.866 & 0.244 & 0.081 & 0.385 \\
\hline Customer's Characteristics & Yes & Yes & Yes & Yes & Yes & Yes & Yes & Yes & Yes & Yes \\
\hline Supplier's Characteristics & Yes & Yes & Yes & Yes & Yes & Yes & Yes & Yes & Yes & Yes \\
\hline Customer-Supply FEs & Yes & Yes & Yes & Yes & Yes & Yes & Yes & Yes & Yes & Yes \\
\hline Year FEs & Yes & Yes & Yes & Yes & Yes & Yes & Yes & Yes & Yes & Yes \\
\hline Cash Flow Constraint & No & No & No & No & No & No & No & No & No & No \\
\hline
\end{tabular}

This table presents panel regressions for suppliers' accounts receivable to total sales, using a manually collected supplier-customer sample. Customer undervaluation $(\widehat{C U N})$ is predicted in the first-stage by regressing the customer's value-to-price ratio on the customer's mutual fund outflow and a set of customers' and suppliers' characteristics. We control for customer features, supplier features, customer-supplier fixed effects, and year fixed effects; t-statistics are in parentheses. Regressions are run for the full sample and for subsamples based on the supplier's size (defined using the supplier's total book assets), the customer pool (defined as the number of customers of a supplier), and the length of the customer-supplier relationship (defined as the number of years elapsed since the first establishment of the customer-supplier relationship). Subsamples are defined based on the tercile of the variable of interest. For brevity, regression coefficients are reported only for the instrumented undervaluation measure for a supplier's customers $\widehat{C U N}$. Standard errors are clustered at the client-supplier level; t-statistics are in parentheses; and ${ }^{* * *}, * *$ and * show that the coefficient is significant at the $1 \%, 5 \%$, and $10 \%$ level, respectively. 


\section{Table IX}

Is the Effect of Firm Undervaluation on Trade Credit Persistent?

\begin{tabular}{|c|c|c|c|c|c|c|}
\hline & (1) & (2) & (3) & (4) & $(5)$ & (6) \\
\hline & & OLS & & & 2SLS & \\
\hline \multirow[t]{2}{*}{$U N_{t-1} / \widehat{U N}_{t-1}$} & $0.18^{* * *}$ & & & $3.00^{* *}$ & & \\
\hline & $(7.40)$ & & & $(2.20)$ & & \\
\hline \multirow[t]{2}{*}{$U N_{t-2} / \widehat{U N}_{t-2}$} & & $0.14^{* * *}$ & & & -0.89 & \\
\hline & & $(5.93)$ & & & $(-0.67)$ & \\
\hline \multirow[t]{2}{*}{$U N_{t-3} / \widehat{U N}_{t-3}$} & & & 0.01 & & & 0.37 \\
\hline & & & $(0.40)$ & & & $(0.40)$ \\
\hline Cash Flow Constraint & Yes & Yes & Yes & Yes & Yes & Yes \\
\hline Firm FEs & Yes & Yes & Yes & Yes & Yes & Yes \\
\hline Year FEs & Yes & Yes & Yes & Yes & Yes & Yes \\
\hline Observations & 39,469 & 39,469 & 39,469 & 39,469 & 39,469 & 39,469 \\
\hline
\end{tabular}




\section{Table X}

\section{Robustness Tests: Alternative Measures, Specifications, and Periods}

\begin{tabular}{|c|c|c|c|c|c|c|c|c|c|}
\hline \multirow{2}{*}{\multicolumn{2}{|c|}{ Estimation Method }} & (1) & (2) & (3) & (4) & $(5)$ & (6) & (7) & (8) \\
\hline & & \multicolumn{6}{|c|}{ All Periods } & Normal Periods & Crisis Periods \\
\hline \multirow[t]{2}{*}{$U N$} & OLS & $0.15^{* * *}$ & $0.14^{* * *}$ & $0.55^{* * *}$ & $0.19^{* * *}$ & $0.20^{* * *}$ & $0.10^{* * * *}$ & $0.15^{* * *}$ & $0.27^{* * *}$ \\
\hline & & $(6.45)$ & $(2.95)$ & $(9.75)$ & $(5.12)$ & (12.12) & $(4.31)$ & $(6.19)$ & $(4.25)$ \\
\hline \multirow[t]{2}{*}{$\widehat{U N}$} & 2SLS & $1.12^{* *}$ & $1.68^{* * *}$ & $4.16^{* * *}$ & $2.19^{* * * *}$ & $1.61^{* * * *}$ & 1.38 & $2.35^{* *}$ & 8.04 \\
\hline & & $(2.31)$ & $(3.20)$ & $(2.14)$ & $(3.05)$ & $(3.29)$ & $(1.30)$ & (1.99) & $(1.00)$ \\
\hline \multicolumn{2}{|c|}{ Cash-Flow Constraint } & Yes & Yes & Yes & Yes & No & Yes & Yes & Yes \\
\hline \multicolumn{2}{|c|}{ Firm Characteristics } & Yes & Yes & Yes & Yes & Yes & Yes & Yes & Yes \\
\hline \multicolumn{2}{|c|}{ Firm FE } & Yes & Yes & Yes & Yes & No & No & Yes & Yes \\
\hline \multicolumn{2}{|c|}{ Industry FE } & No & No & No & No & Yes & Yes & No & No \\
\hline \multicolumn{2}{|c|}{ Year FE } & Yes & Yes & Yes & Yes & Yes & Yes & Yes & Yes \\
\hline \multicolumn{2}{|c|}{ Observations } & 58,115 & 51,109 & 51,109 & 21,400 & 51,109 & 51,109 & 42,356 & 8,753 \\
\hline
\end{tabular}

This table reports the results of a variety of robustness checks. Column (1) reports the estimates for the instrumented value-to-price ratio, including firms with negative terminal value. Column (2) reports the estimates for the instrumented book-to-price ratio. Column (3) reports the estimates for Kropf, Robinson, and Viswanathan's (2005) firm-specific error. Column (4) provides estimates for the instrumented value-to-price ratio, with the firm's intrinsic value computed using analysts' median EPS forecasts from I/B/E/S/. Column (5) reports the estimates applying the seemingly unrelated regression model. Column (6) reports the estimates for the instrumented value-to-price ratio in the net trade credit regressions. Columns (7) and (8) compare the normal periods and the crisis periods. For brevity, regression coefficients are reported only for the undervaluation measures; ${ }^{* * *},{ }^{* *}$, and ${ }^{*}$ show that the coefficient is significant at the $1 \%, 5 \%$, and $10 \%$ level, respectively. 